DOI:

Cite this as:

Luhulima, Hendro Valence. Implementation Of Devotional Rights On Accessibility And Communication Based On Undang-Undang Nomor 8 Tahun 2016 Concerning Disabilities. Indonesian Journal of Disability Studies (IJDS).2018: Vol. 5(2): PP 268-295.

\title{
IMPLEMENTATION OF DEVOTIONAL RIGHTS ON ACCESSIBILITY AND COMMUNICATION BASED ON UNDANG- UNDANG NOMOR 8 TAHUN 2016 CONCERNING DISABILITIES
}

\author{
Hendro Valence Luhulima \\ ${ }^{1}$ Fakultas Hukum Universitas Gajah Mada,.Jalan Socio Justicia No 1 Bulaksumur, Sleman, DIY, Indonesia
}

\begin{abstract}
This research discusses the implementation of the right of the Deaf to accessibility and communication by the Government of Indonesia based on Law No. 8 of 2016 concerning Persons with Disabilities. Normative-empirical legal research used in this research. Due to time constraints, sampling was limited to Yogyakarta Special Region based on purposive sampling. This research does not focus on efforts to generalize, but rather emphasizes the meaning of a phenomenon under study. The results of this research is that the rights of Deaf people to accessibility and communication have not been fully implemented according to the mandate of Law No. 8 of 2016 concerning Persons with Disabilities. However, this does not mean that the rights of the Deaf are not fulfilled at all, but in the stage of development. This is because there are two conditions that researcher find among Deaf people, namely Deaf people whose rights have been fulfilled, and Deaf people whose rights have not been fulfilled.
\end{abstract}

Keywords: deaf people, right to communication, right to accessibility

\section{Pendahuluan}

Pengaturan mengenai Penyandang Disabilitas di Indonesia pada awalnya dimulai pada masa Pemerintahan Soeharto, yaitu dengan dibentuknya Undang-Undang Nomor 4 Tahun 1997 tentang Penyandang Cacat. Pembentukan undang-undang ini dilatarbelakangi oleh adanya peningkatan jumlah penyandang cacat, dan Pemerintah merasa perlu untuk mengupayakan peningkatan kesejahteraan sosial bagi penyandang cacat $^{1}$ dalam rangka mencapai tujuan pembangunan

\section{* Corresponding author: Hendro Valence Luhulima luhulimahendro@gmail.com \\ Published online at http://IJDS.ub.ac.id/ \\ Copyright @ 2018 PSLD UB Publishing. All Rights Reserved}

\footnotetext{
${ }^{1}$ Istilah penyandang cacat mempunyai konotasi yang negatif, sehingga dalam penulisan ini akan digunakan istilah Penyandang Disabilitas sesuai dengan terjemahan istilah yang digunakan dalam CRPD.
}

pengaturan mengenai Penyandang Disabilitas juga diatur diantara negara-negara dalam tingkatan internasional. Pada 13 Desember nasional. ${ }^{2}$ Selain dalam level nasional, 2006, negara anggota Perserikatan Bangsa-Bangsa merancang sebuah instrumen internasional yaitu United Nations Convention on the Rights of Persons with Disabilities (CRPD). Sebagai negara anggota $\mathrm{PBB}$, Indonesia turut terlibat dalam pembahasan mengenai CRPD, kemudian menandatangani CRPD pada tanggal 30 Maret 2007, tanpa reservasi. Penandatanganan tersebut menunjukan kesungguhan negara Indonesia untuk menghormati, melindungi, memenuhi, dan memajukan hak-hak Penyandang Disabilitas. ${ }^{3}$

\footnotetext{
${ }^{2}$ Lihat konsideran UU No. 4 Tahun 1997 tentang Penyandang Cacat.

${ }^{3}$ Lihat Penjelasan Umum Undang-Undang Nomor 19 Tahun 2011 tentang Pengesahan Convention on the Rights of Persons with Disabilities (Konvensi mengenai Hak-Hak Penyandang Disabilitas).
} 
Jika dibandingkan antara UU No. 4 Tahun 1997 tentang Penyandang Cacat dengan CRPD, ternyata CRPD lebih banyak mengakomodasi hak-hak Penyandang Disabilitas. Sebagai contoh, dalam CRPD dirincikan mengenai langkah-langkah seperti apa yang perlu dilakukan agar ada aksesibilitas untuk orang Penyandang Disabilitas. ${ }^{4}$ Sedangkan UU No. 4 Tahun 1997 tentang Penyandang Cacat hanya menyatakan bahwa semua penyandang cacat berhak untuk mendapatkan aksesibilitas untuk kemandirian, dan mewajibkan Pemerintah dan/atau masyarakat untuk menyediakan hal tersebut tanpa menjelaskan lebih jauh langkahlangkah penyediaan aksesibilitas yang dimaksud..$^{5}$ Bukan hanya itu saja, paradigma yang dibentuk oleh UU No. 4 Tahun 1997 tentang Penyandang Cacat lebih menekankan bahwa Penyandang Disabilitas itu sebagai objek, bukan sebagai subjek yang memang sudah seharusnya mempunyai hak yang sama dengan yang lainnya.

Kelemahan UU No. 4 Tahun 1997 tentang Penyandang Cacat kemudian menjadi catatan reflektif bagi Pemerintah untuk membuat Undang-Undang Nomor 8 Tahun 2016 tentang Penyandang Disabilitas yang disahkan oleh Presiden Joko Widodo pada 15 April 2016. Pengaturan yang baru ini hendak merubah paradigma sebelumnya dengan lebih memperkenalkan perspektif HAM bagi Penyandang Disabilitas. Peraturan tersebut juga dibentuk sebagai respon atas diratifikasinya CRPD oleh Indonesia.

Berdasarkan klasifikasi Penyandang Disabilitas yang ada dalam UU No. 8 Tahun 2016, kuantitas orang Tuli sangat banyak jika dibandingkan dengan Penyandang Disabilitas lainnya. Berdasarkan catatan World Health Organization (WHO) pada tahun 2012, Indonesia menempati urutan keempat di tingkat Asia atau sekitar 13 ribu penduduk memiliki gangguan pendengaran atau ketulian, setelah Sri Lanka, Myanmar, dan India. ${ }^{6}$ Banyaknya jumlah orang Tuli di Indonesia mengindikasi bahwa mereka sebagai salah satu golongan

\footnotetext{
${ }^{4}$ Lihat Pasal 9 CRPD.
${ }^{5}$ Lihat Pasal 6 dan Pasal 10 UU No. 4 Tahun 1997 tentang

${ }^{4}$ Lihat Pasal 9 CRPD.
${ }^{5}$ Lihat Pasal 6 dan Pasal 10 UU No. 4 Tahun 1997 tentang Penyandang Cacat.

${ }^{6}$ World Health Organization, "Who Global Estimates on

Prevalence of Hearing Loss",

Prevalence of Hearing Loss",
http://www.who.int/pbd/deafness/WHO GE HL.pdf?ua= $\underline{1}$, diakses 2 Maret 2018.
}

Cite this as:

Luhulima, Hendro Valence. Implementation Of Devotional Rights On Accessibility And Communication Based On Undang-Undang Nomor 8 Tahun 2016 Concerning Disabilities. Indonesian Journal of Disability Studies (IJDS).2018: Vol. 5(2): PP 268-295. masyarakat yang perlu mendapatkan perhatian lebih dari Pemerintah Indonesia.

Sebagai negara penandatangan (contracting state) sekaligus yang telah meratifikasi CRPD, Indonesia dibebani kewajiban dalam konvensi tersebut untuk melakukan penyesuaian terhadap peraturan perundang-undangan, hukum, maupun administratif yang masih bersifat diskriminatif. Indonesia dituntut untuk turut serta melakukan tindakan nyata terkait pemenuhan hak-hak orang Penyandang Disabilitas, termasuk orang Tuli. ${ }^{7}$

Kebutuhan akan komunikasi merupakan hal yang sangat mendasar bagi orang Tuli. Komunikasi yang dimaksud mencakup Bahasa Isyarat dan tayangan teks sebagaimana ditegaskan dalam Pasal 2 CRPD. Tanpa adanya akses kepada hak tersebut, orang Tuli akan kesulitan dalam memenuhi hak-haknya yang lain, misalnya hak untuk bekerja. Mayoritas Penyandang Disabilitas yang diterima bekerja adalah tunanetra atau orang berkusi roda. Hal ini disebabkan karena orang berkursi roda maupun tunanetra bisa diajak berkomunikasi, sementara proses berkomunikasi dengan orang Tuli berjalan lambat. ${ }^{8}$

Permasalahan orang Tuli tidak berhenti sampai disitu saja. Sebagai contoh, pengumuman yang disampaikan di Bandar Udara, Terminal, maupun Stasiun Kereta. Pengumuman tersebut biasanya disampaikan melalui pengeras suara. Bagi orang dengar, hal tersebut merupakan sesuatu yang lumrah, tetapi merupakan hal yang sebaliknya bagi orang Tuli. Orang Tuli akan mengalami kesulitan dalam menerima informasi yang disampaikan jika fasilitas umum/pelayanan publik masih mengandalkan bunyi/suara dan oral. ${ }^{9}$

Berkaca pada kenyataan tersebut, paling tidak terdapat dua hak orang Tuli yang disoroti dalam pandangan peneliti, yaitu mengenai aksesibilitas dan hak untuk berkomunikasi. Aksesibilitas lebih mengarah kepada ketersediaan kesempatan yang seluas-luasnya bagi orang Tuli untuk dapat berpartisipasi

\footnotetext{
${ }^{7}$ Lihat Pasal 4 CRPD.

${ }^{8}$ Adhi Kusumo Bharoto dalam "Hak Penyandang Tuli Terabaikan", Kompas, 6 Maret 2017.

${ }^{9}$ Didi Tarsidi, "Kendala Umum yang dihadapi Penyandang Disabilitas dalam Mengakses Layanan Publik", Jassi Anakku, Volume 10, Nomor 2, 2011, hlm. 203. Lihat juga Blaine Goss, "Hearing for the Deaf Culture", Intercultural Communication Studies, Volume 12, Nomor 2, 2003, hlm. 1.
} 269 
penuh dalam semua aspek kehidupan. Sedangkan hak untuk berkomunikasi merupakan hal fundamental yang sangat dibutuhkan oleh orang Tuli untuk menjalankan aktivitas kesehariannya. Untuk dapat mengetahui sejauh mana implementasi hak orang Tuli atas aksesibilitas, dan hak untuk berkomunikasi, tentu dibutuhkan penelitian lebih lanjut.

\section{Metodologi}

\subsection{Jenis Penelitian/Bahan Penelitian}

Penelitian ini menggunakan jenis penelitian hukum normatif-empiris. Penelitian hukum normatif-empiris adalah penelitian hukum mengenai pemberlakuan atau implementasi ketentuan hukum normatif secara in action pada setiap peristiwa hukum tertentu yang terjadi dalam masyarakat ${ }^{10}-$ dalam hal ini mengenai implementasi hak orang Tuli atas aksesibilitas dan hak untuk berkomunikasi berdasarkan UU No. 8 Tahun 2016 tentang Penyandang Disabilitas. Penelitian ini akan berfokus pada norma hukum nasional dan internasional yang mengatur tentang Penyandang Disabilitas, dan HAM sebagai data sekunder, dan wawancara di lapangan sebagai data primer.

Penelitian ini menggunakan pendekatan kualitatif. Pendekatan kualitatif merupakan sebuah pendekatan yang meneliti suatu objek yang alamiah di mana peneliti berfungsi sebagai instrumen kunci. Analisis data bersifat induktif, dan hasil penelitiannya lebih ditekankan kepada makna daripada generalisasi suatu fenomena yang diteliti. ${ }^{11}$

\subsection{Lokasi Penelitian}

Penelitian ini akan dilakukan pada Daerah Istimewa Yogyakarta berdasarkan cara purposive sampling. Purposive sampling adalah metode pengambilan sampel yang dipilih dengan mendasarkan pada tujuan penelitian atau pertimbangan tertentu. ${ }^{12}$ Berkaitan dengan hal tersebut, peneliti memilih Daerah Istimewa Yogyakarta dengan memperhatikan bahwa Yogyakarta merupakan salah satu dari sembilan provinsi di Indonesia yang memiliki angka

\footnotetext{
${ }^{10}$ Abdulkadir Muhammad, 2004, Hukum dan Penelitian Hukum, Bandung: PT Citra Aditya Bakti, hlm. 134.

11 Sugiyono, 2014, Memahami Penelitian Kualitatif, Bandung: Alfabeta, hlm. 1

12 Ibid., hlm. 53-54.
}

prevalensi gangguan pendengaran yang melebihi angka rata-rata nasional $(2,6 \%)$ berdasarkan data dari Badan Pelatihan dan Pengembangan Kementerian Kesehatan. ${ }^{13}$ Dengan tingkat prevalensi gangguan pendengaran tersebut mempunyai resiko terhadap ketulian. Yogyakarta juga termasuk dalam lima belas provinsi yang memiliki prevalensi ketulian diatas rata-rata nasional $(0,9 \%)$ sebagaimana ditunjukan dalam hasil Riset Kesehatan Dasar Tahun 2013 oleh Badan Penelitian dan Pengembangan Kesehatan Kementerian Kesehatan. ${ }^{14}$

Peneliti menyadari bahwa pengambilan sampel yang hanya terbatas pada Daerah Istimewa Yogyakarta sebagai objek penelitian ini tidak dapat secara langsung mengeneralisir bahwa hak-hak orang Tuli atas aksesibilitas dan hak berkomunikasi sudah atau belum dilaksanakan oleh Pemerintah Indonesia. Tetapi lewat kajian ini diharapkan menjadi suatu catatan reflektif bagi Indonesia yang telah berkomitmen untuk melindungi, menghargai, dan memenuhi hak-hak Penyandang Disabilitas, in casu orang Tuli.

\section{Tinjauan Pusataka}

\subsection{Tuli atau Tunarungu}

Setiap orang dalam berkomunikasi selalu berusaha untuk dapat menggunakan kata-kata yang halus dan sopan, apalagi hal tersebut berhubungan dengan orang yang memiliki keterbatasan kemampuan atau kelemahan untuk melakukan sesuatu. Penyebutan atau sapaan dengan menggunakan kata-kata tertentu dilakukan dengan maksud agar tidak menyakiti perasaan orang yang memiliki keterbatasan kemampuan tadi.

Bahasa Indonesia mengenal "kata-kata halus" tersebut. Sebagai contoh untuk

\footnotetext{
${ }^{13}$ Lihat Kementerian Kesehatan, "Rencana Strategis Kemenkes Tanggulangi Gangguan Pendengaran", http://www.depkes.go.id/article/view/17030300004/renc ana-strategis-kemenkes-tanggulangi-gangguanpendengaran.html, diakses 16 April 2018.

${ }^{14}$ Data yang digunakan ialah Data Riset Kesehatan Dasar (Riskesdas) tahun 2013 karena Riskesdas merupakan sebuah riset yang diadakan setiap lima tahun sekali, dan riset ini merupakan riset yang terakhir kali dikeluarkan oleh Kementerian Kesehatan sesudah tahun 2007, dan 2010. Lihat Badan Penelitian dan Pengembangan Kesehatan, 2013, Riset Kesehatan Dasar 2013, Hasil Penelitian, Kementerian Kesehatan Republik Indonesia, Jakarta, hlm. 245.
}

Cite this as:

Luhulima, Hendro Valence. Implementation Of Devotional Rights On Accessibility And Communication Based On Undang-Undang Nomor 8 Tahun 2016 Concerning Disabilities. Indonesian Journal of Disability Studies (IJDS).2018: Vol. 5(2): PP 268-295. 
menyebut orang dengan keterbatasan kemampuan, seseorang lebih memilih untuk menggunakan kata Penyandang Disabilitas daripada Penyandang Cacat. Untuk lebih spesifiknya, orang yang tidak bisa melihat dikatakan tunanetra, lalu ada tunarungu untuk orang yang tidak bisa mendengar, tunagrahita terhadap orang yang memiliki keterbelakangan mental, tunawicara bagi yang tidak bisa berbicara, dan sebagainya. Kata-kata tersebut lebih terdengar sopan dan memiliki konotasi yang positif.

Kendati demikian, ada suatu fenomena menarik yang terjadi di kalangan orang yang tidak bisa mendengar. Kelompok ini lebih senang dan nyaman jika dipanggil dengan sebutan orang Tuli, daripada dipanggil tunarungu. Tuli lebih mengandung arti yang positif daripada tunarungu. Hal tersebut diungkapkan oleh Disabilities, Opportunities, Internetworking, and Technology Center (DOIT) sebagai berikut.

Many individuals who are deaf or hard of hearing prefer the terms "deaf" and "hard of hearing," because they consider them to be more positive than the term "hearing impaired," which implies a deficit or that something is wrong that makes a person less than whole. ${ }^{15}$

Bagi orang awam, kedua istilah tersebut Tuli dan tunarungu - mempunyai makna yang sama saja karena akan merujuk pada orang yang tidak dapat mendengar. Perbedaannya hanya terletak pada halus atau tidaknya jikalau digunakan. Perbedaan yang dimengerti oleh orang awam sudah tepat, tetapi penempatan mana yang positif dan negatif itu yang berbeda bagi orang Tuli, dan komunitasnya.

Di dalam sudut pandang orang Tuli dan komunitasnya, Tuli dan tunarungu mempunyai pengertian yang berbeda. Tunarungu merupakan istilah yang diperkenalkan dalam dunia kedokteran. Tunarungu diartikan sebagai sebuah kelainan atau kerusakan pada indera pendengar. Kerusakan maupun ketidakmampuan mendengar tersebut disebabkan oleh beberapa faktor seperti sakit, kecelakaan, bertambahnya umur, kelainan

${ }^{15}$ DO-IT, "How are the terms deaf, deafened, hard of hearing, and hearing impaired typically used?", https://www.washington.edu/doit/how-are-terms-deafdeafened-hard-hearing-and-hearing-impaired-typicallyused, diakses 9 Maret 2018. syaraf, dan hal-hal lain yang erat kaitannya dengan masalah fisik pada indera pendengar. ${ }^{16}$ Jadi dapat disimpulkan bahwa tunarungu merupakan sebuah diagnosis medikal yang mengidentifikasi adanya kerusakan pada indera pendengar, atau kondisi pendengaran yang rusak.

Berbeda dengan tunarungu, kata "Tuli" mempunyai makna yang lebih luas. Istilah tersebut tidak merujuk pada kerusakan, melainkan pada kebudayaan, dan suatu identitas. Mereka dilahirkan pada keadaan yang normal, hanya saja memiliki perbedaan budaya, cara berkomunikasi dengan bahasa yang berbeda. ${ }^{17} \mathrm{Hal}$ senada juga disampaikan oleh The State of Queensland Government sebagai berikut.

Deaf people - 'Deaf' (with a capital'D') refers to those who are part of a Deaf community with their own language, culture, values and beliefs. Deaf people identify as "Culturally Deaf" and prefer to view themselves as being part of a culturally and linguistically diverse group (CALD) rather than as a person with a disability (PWD). ${ }^{18}$

Berdasarkan penjelasan diatas, dapat disimpulkan bahwa istilah Tuli, lebih mengacu pada kelompok minoritas linguistik yang menggunakan Bahasa Isyarat, juga terkait dengan budaya dan identitas. ${ }^{19}$ Dikarenakan Tuli merupakan suatu identitas - sama seperti nama orang - maka penulisannya pun harus menggunakan huruf kapital diawalnya, sehingga menjadi Tuli bukan tuli. Orang Tuli mempunyai hak yang sama dengan orang dengar, namun karena orang Tuli mempunyai ciri khas tersendiri, orang dengar wajib untuk memberikan perlakuan khusus bagi mereka

\footnotetext{
${ }^{16}$ Nick Palfreyman, "Budaya Tuli Indonesia dan Hak Bahasa", Coference Paper, Seminar Tahunan Linguistik, Universitas Pendidikan Indonesia, 4-5 Juni 2015, hIm. 1.

${ }^{17}$ Louise Munro, 2010, The Development and Evaluation of a Culturally Affirmative Counseling Model for Deaf Clients in Australia, Desertasi, Faculty of Health Queensland University of Technology, Queensland, hlm. 267-268.

${ }^{18}$ Queensland Health Multicultural Services, "How to Work with a Person who is Deaf or Hearing Impaired",https://www.health.qld.gov.au/ data/assets/ pdf file/0024/157362/howtoworkwithdeaf.pdf, diakses 18 September 2018.

19 Adang Iskandar, "Peduli Tuli", http://mediaindonesia.com/news/read/133795/peduli271 
dalam rangka mewujudkan adanya kesetaraan hak-hak untuk orang Tuli.

\subsection{Konsep mengenai Komunikasi}

Komunikasi berasal dari akar kata communico, yang artinya berbagi. Berbagi yang dimaksud pada pengertian communico ialah berbagi pemahaman yang sama melalui pesan. Kata communico kemudian berkembang ke dalam Bahasa Latin, yaitu communis yang artinya membuat kebersamaan atau membangun kebersamaan antara dua orang atau lebih. ${ }^{20}$ Dari kedua kata tersebut, menandakan bahwa dalam komunikasi setidaknya mengandung aspek berbagi diantara komunikator dan komunikan, kebersamaan atau pemahaman, dan pesan. Dengan demikian, secara harafiah, yang dimaksud dengan komunikasi ialah proses berbagi pesan yang disampaikan dari satu pihak ke pihak lainnya dengan tujuan untuk memperoleh pemahaman. ${ }^{21}$

Seseorang tidak dapat dikatakan berkomunikasi apabila tidak ada pesan yang disampaikan di dalam proses tersebut. Kendati demikian, hadirnya pesan tidak serta-merta membuat komunikasi itu ada, sebab jika pesan itu tidak tersampaikan dengan baik dari satu pihak ke pihak lain maka disini telah terjadi kegagalan komunikasi. Di dalam proses komunikasi terdapat istilah yang disebut dengan efek komunikasi. Efek komunikasi ialah suatu perubahan kondisi yang terjadi pada komunikan setelah menerima pesan. ${ }^{22}$ Efek komunikasi sering menjadi faktor penentu keberhasilan komunikasi. Apabila sikap dan tingkah laku komunikan sesuai dengan yang diharapkan komunikator, maka pesan yang ada dalam proses komunikasi tepat sasaran. Dengan demikian, komunikasi telah berjalan dengan baik, begitu pula sebaliknya. ${ }^{23}$

Berdasarkan penjelasan di atas, Pawit M. Yusup mengatakan bahwa yang sangat menentukan berhasil atau tidaknya komunikasi adalah faktor manusia. Kemudian Yusup memberi saran bahwa apabila seseorang mempelajari komunikasi maka ia harus

\footnotetext{
${ }^{20}$ Nurudin, 2017, Ilmu Komunikasi: Ilmiah dan Populer, Jakarta: Rajawali Pers, hlm. 8.

${ }^{21}$ Lihat Ibid.

22 Santoso Sastropoetro, 1991, Propaganda Salah Satu Bentuk Komunikasi Massa, Bandung: Alumni, hlm. 89.

${ }^{23}$ Suryanto, 2015, Pengantar Ilmu Komunikasi, Bandung: Pustaka Setia, hlm. 194.
}

mempelajari manusia dengan segala keunikannya. ${ }^{24}$

\subsection{Konsep mengenai Aksesibilitas}

Konsep mengenai aksesibilitas juga diatur dalam UU No. 8 Tahun 2016 tentang Penyandang Disabilitas. Menurut Pasal 1 angka 8 UU No. 8 Tahun 2016 tentang Penyandang Disabilitas, yang dimaksud dengan aksesibilitas adalah suatu kemudahan yang disediakan bagi Penyandang Disabilitas dalam rangka mewujudkan kesamaan kesempatan. Sejalan dengan itu, Peraturan Menteri Pekerjaan Umum Nomor 30/PRT/M/2006 tentang Pedoman Teknis Fasilitas dan Aksesibilitas pada Bangunan Gedung dan Lingkungan juga menegaskan bahwa aksesibilitas merupakan kemudahan yang disediakan bagi semua orang, termasuk Penyandang Disabilitas dan lansia untuk mewujudkan kesamaan kesempatan dalam segala aspek kehidupan. ${ }^{25}$

Eko Widyonarso dan Nany Yuliastuti menyampaikan pandangannya bahwa konsep kemudahan yang ada dalam pengertian aksesibilitas merupakan sesuatu hal yang sifatnya subjektif, dan kualitatif. Mudah bagi seseorang belum tentu mudah bagi orang lain. Oleh karena itu, diperlukan kinerja kuantitatif yang dapat menyatakan aksesibilitas atau kemudahan. Kendati demikian, Widyonarso dan Yuliastuti mengatakan bahwa poin penting dari aksesibilitas ialah kemudahan mengakses tujuan yang dapat memberikan kenyamanan beraktivitas. ${ }^{26}$

\section{Hasil Penelitian dan Pembahasan}

\subsection{Hak atas Komunikasi}

Manusia sebagai makhluk sosial selalu berkeinginan untuk menjalin hubungan dengan manusia yang lainnya. Orang tersebut ingin mengetahui lingkungannya, bahkan ingin mengetahui apa yang terjadi dalam dirinya.

\footnotetext{
${ }^{24}$ Pawit M. Yusup, 2009, IImu Informasi, Komunikasi, dan Kepustakaan, Jakarta: Bumi Aksara, hlm. 5.

${ }^{25}$ Lihat Pasal 1 angka 3 Peraturan Menteri Pekerjaan Umum Nomor 30/PRT/M/2006 tentang Pedoman Teknis Fasilitas dan Aksesibilitas pada Bangunan Gedung dan Lingkungan.

${ }^{26}$ Eko Setyo Widyonarso dan Nany Yuliastuti, "Tingkat Aksesibilitas Fasilitas Sosial berdasarkan Konsep Unit Lingkungan di Perumnas Banyumanik Kota Semarang", Jurnal Ruang, Volume 2, Nomor 4, 2014, hlm. 315.
} 272

Cite this as:

Luhulima, Hendro Valence. Implementation Of Devotional Rights On Accessibility And Communication Based On Undang-Undang Nomor 8 Tahun 2016 Concerning Disabilities. Indonesian Journal of Disability Studies (IJDS).2018: Vol. 5(2): PP 268-295. 
Keingintahuan ini yang memaksakan seseorang untuk berkomunikasi. ${ }^{27}$

Di dalam kehidupan bermasyarakat, seseorang yang tidak pernah berkomunikasi dengan orang lain niscaya akan terisolasi dari masyarakatnya. Pengaruh keterisolasian ini akan menimbulkan depresi mental yang pada akhirnya menyebabkan orang tersebut kehilangan keseimbangan jiwa. Sehubungan dengan hal tersebut, Dr. Everet Kleinjan dari East West Center Hawaii mengatakan bahwa komunikasi sudah menjadi bagian kekal dalam kehidupan seseorang, ia perlu berkomunikasi untuk dapat bertahan hidup. ${ }^{28}$

Harold Lasswell dengan model komunikasinya mengatakan bahwa terdapat tiga fungsi dasar yang dapat menjustifikasi seseorang perlu untuk berkomunikasi dengan orang lain yaitu sebagai berikut.

a. Hasrat manusia untuk mengawasi lingkungan. Menurut Lasswell, seseorang perlu menyadari setiap kejadian yang terjadi di lingkungan sekitarnya apabila ia ingin telibat dalam kehidupan sosial, dan mengambil tanggung jawab di dalamnya. ${ }^{29}$ Untuk mengetahui hal tersebut, komunikasi menjadi satusatunya cara yang dapat digunakan. Dengan komunikasi, seseorang dapat mengetahui peluang-peluang yang ada untuk dimanfaatkan bagi pengembangan diri pribadi, maupun menghindari ancaman-ancaman yang dapat membahayakan lingkungannya. ${ }^{30}$

b. Upaya manusia untuk dapat beradaptasi dengan lingkungannya. Fungsi ini menegaskan bahwa proses kelanjutan suatu masyarakat sesungguhnya bergantung pada bagaimana masyarakat itu merespon lingkungannya kemampuan beradaptasi. Kemampuan beradaptasi ini tidak hanya terletak pada kemampuan manusia memberi tanggapan

\footnotetext{
${ }^{27}$ H. Hafied Cangara, 2015, Pengantar Ilmu Komunikasi, Jakarta: Rajawali Press, hlm. 1.

${ }^{28} \mathrm{lbid}$.

${ }^{29}$ Zahra Abazari dan Mahshid Borjian Brojeni, "The Role of Harold Laswell Communication Theory in Librarianship and Information Science", International Academics Journal of Humanities, Volume 4, Nomor 2, 2017, hlm. 89.

${ }^{30}$ Ardylas Y. Putra, "Strategi BNN (Badan Narkotika Nasional) Kota Samarinda dalam Mensosialisasikan Bahaya Narkoba", Jurnal IImu Komunikasi, Volume 2, Nomor 2, 2014, hlm. 80.
}

terhadap gejala alam, melainkan juga lingkungan masyarakat tempat manusia hidup dalam tantangan. ${ }^{31}$

c. Upaya untuk melakukan transformasi warisan sosial dari generasi yang satu ke generasi yang lain. Suatu kelompok masyarakat yang ingin tetap mempertahankan eksistensinya dituntut untuk melakukan pertukaran nilai, perilaku, dan peranan dari generasi ke generasi. ${ }^{32}$ Pertukaran ini menjadi penting sebab setiap generasi mempunyai pengalaman yang berbeda. Harapannya, hal ini dapat menjadi suatu pelajaran sehingga generasi berikutnya tetap melestarikan apa yang selama ini dianut dari generasi sebelumnya. ${ }^{33}$

Ketiga fungsi di atas menjadi patokan dasar bagi setiap individu untuk menjalin hubungan dengan sesama anggota masyarakat. Hal tersebut akan tercapai apabila manusia satu dengan yang lainnya saling berkomunikasi, dan terjadi pertukaran informasi di dalamnya. Berangkat dari pemikiran tersebut, tidak mengherankan apabila instrumen hukum internasional maupun nasional negara mana pun menjamin setiap orang - tanpa terkecuali untuk dapat memperoleh hak atas komunikasi.

Bagi orang Tuli, hak atas komunikasi merupakan salah satu elemen penting dalam kehidupan mereka. Hak ini dianggap sebagai pintu masuk bagi pemenuhan hak-hak yang lainnya, karena ketika seorang Tuli berkomunikasi dengan orang lain, baik itu orang dengar maupun sesama Tuli akan ada informasi-informasi tertentu yang mereka dapatkan. Informasi ini akan memberikan petunjuk kepada orang Tuli dalam pemenuhan kebutuhan hidup mereka sehari-hari.

Sebagaimana telah dijelaskan pada bagian tinjauan pustaka mengenai komunikasi, dikatakan bahwa hasil akhir dari komunikasi ialah pesan yang disampaikan dapat diterima dengan baik oleh para pihak. Untuk mencapai hasil akhir tersebut, tentu sangat dipengaruhi oleh beberapa elemen, seperti komunikator, dan komunikan. Kedua unsur ini diperlu diperhatikan sebab interkasi dan proses pertukaran informasi dapat terjadi ketika kedua elemen ini muncul. Alasan berikutnya ialah

\footnotetext{
${ }^{31}$ H. Hafied Cangara, Op. Cit., hlm. 3.

${ }^{32}$ Ibid.

${ }^{33}$ Zahra Abazari dan Mahshid Borjian Brojeni, Op. Cit., hlm. 89-90.
}

Cite this as:

Luhulima, Hendro Valence. Implementation Of Devotional Rights On Accessibility And Communication Based On Undang-Undang Nomor 8 Tahun 2016 Concerning Disabilities. Indonesian Journal of Disability Studies (IJDS).2018: Vol. 5(2): PP 268-295. 
pesan sebagai salah satu unsur dari komunikasi asalnya dari komunikator, dan kemudian pesan itu diteruskan kepada komunikan untuk direspon. Sederhananya, pesan tidak akan muncul apabila tidak ada komunikator yang menyampaikannya, dan pesan itu tidak akan tersampaikan apabila tidak ada sasaran yang dituju (komunikan).

Berbicara mengenai komunikator dan komunikan tentu berkaitan erat dengan faktor manusianya. Masing-masing pihak perlu memahami dan mengetahui dengan pasti kapasitas diri lawan bicaranya agar pesan yang disampaikan dapat diterima dengan baik. ${ }^{34} \mathrm{Hal}$ yang sama juga berlaku ketika berkomunikasi dengan orang Tuli. Sebagai orang dengar, ketika hendak berbicara dengan orang Tuli perlu memahami dan mengetahui bagaimana caranya agar pesan yang ingin disampaikan dapat diterima dengan baik oleh orang Tuli. Orang dengar tentu menyadari bahwa orang Tuli tidak dapat mendengar perkataan yang disampaikan oleh orang lain, artinya bahasa lisan tidak efektif untuk digunakan ketika berkomunikasi dengan orang Tuli. Oleh sebab itu, orang dengar perlu mencari alternatif lain yang dapat digunakan agar bisa berkomunikasi secara baik dengan orang Tuli.

Adanya perkembangan teknologi seperti sekarang ini, handphone dapat dijadikan sebagai salah satu pilihan dalam berkomunikasi dengan orang Tuli. Orang dengar yang baru pertama kali bertemu dengan orang Tuli akan menggunakan cara ini untuk berkomunikasi dengannya. ${ }^{35}$ Selain cara tersebut, orang dengar juga terkadang menggunakan tulisan untuk menyampaikan informasi kepada orang Tuli. Namun, cara-cara ini tidak sepenuhnya efisien dan efektif karena akan memakan waktu yang cukup lama apabila terdapat banyak hal yang ingin disampaikan - lebih dari sekedar menanyakan kabar.

Peneliti tentu mengapresiasi orang dengar yang tetap berusaha berkomunikasi dengan orang Tuli menggunakan cara-cara yang disebutkan di atas. Namun di lain pihak, hal tersebut masih di rasakan kurang sebab orang Tuli mempunyai cara berkomunikasi yang berbeda, yaitu dengan menggunakan Bahasa Isyarat. Bahasa Isyarat merupakan identitas asli

\footnotetext{
${ }^{34}$ H. Hafied Cangara, Op. Cit., hlm. 29.

${ }^{35}$ Berdasarkan hasil Wawancara dengan Kaysha Ainayya Sasdiyarto, Ketua Unit Kegiatan Mahasiswa Peduli Difabel Universitas Gadjah Mada, tertanggal 7 September 2018.
}

dari orang Tuli, bahasa yang berfungsi penuh dan bukan pengganti bahasa lisan. ${ }^{36}$ Pekerjaan para linguis seperti Bernard Tervoort dan William Stokoe pada 1950-an dan 1960-an telah menjadi paradigmatik dalam memperlakukan Bahasa Isyarat sebagai bahasa asli daripada cara-cara primitif untuk bertukar pesan-pesan sederhana seperti cara berpikir orang saat ini. ${ }^{37} \mathrm{Hal}$ ini yang kemudian menjadikan orang Tuli sebagai kelompok minoritas linguistik yang mempunyai budaya, dan identitas yang berbeda. ${ }^{38}$

Bahasa pada dasarnya merupakan sarana komunikasi diantara anggota masyarakat. Di dalam ekspresi budaya, bahasa adalah aspek mendasar yang digunakan untuk menyampaikan tradisi dan nilai-nilai yang terkait dengan identitas kelompok. ${ }^{39}$ Dengan demikian dapat disimpulkan bahwa keberadaan bahasa mempunyai peranan yang sangat penting, termasuk Bahasa Isyarat bagi orang Tuli. Sejalan dengan hal tersebut, Rita Izsák mengatakan bahwa bahasa sangat penting bagi komunitas minoritas linguistik yang berusaha mempertahankan identitas kelompok dan budaya mereka yang berbeda-beda, baik dalam kondisi marjinalisasi, eksklusi, dan diskriminasi. Menurut Izsák, hak minoritas linguistik adalah kewajiban hak asasi manusia ${ }^{40}$ yang harus dipenuhi. Berangkat dari pemikiran tersebut, apabila seseorang berkomunikasi dengan orang Tuli menggunakan Bahasa Isyarat, maka secara tidak langsung orang tersebut telah mengakui dan menghormati eksistensi orang Tuli, termasuk melestarikan kebudayan orang Tuli tersebut.

Para pembentuk UU No. 8 Tahun 2016 tentang Penyandang Disabilitas tampaknya mengetahui dan memahami betapa pentingnya

\footnotetext{
${ }^{36}$ Kajian Tuli oleh Adhi Kusumo Bharoto, "Identitas dan Budaya Tuli", disampaikan pada orientasi Kelas Bahasa Isyarat Indonesia pada tanggal 15 September 2018 di Youth Centre, Sleman, Daerah Istimewa Yogyakarta.

${ }^{37}$ Anja Hiddinga dan Onno Crasborn, "Signed Languages and Globalization", Language Society, Volume 40, Nomor 4, 2011, hlm. 484.

${ }^{38}$ Adang Iskandar, Loc. Cit.

${ }^{39}$ Anca Sirbu, "The Significance of Language as a Tool of Communication", Scientific Bulletin Mircea cel Batran Naval Academy, Voume 18, Nomor 2, 2015, hlm. 405.

${ }^{40}$ Pernyataan Izsák tersebut dikutip dalam Carla A. McNelly, "Language Learning Policy through the Lens of Language as a Problem, as a Right, and as a Resources", NABE Journal of Research and Practice, Volume 6, Nomor 1, 2015, hlm. 9.
}

Luhulima, Hendro Valence. Implementation Of Devotional Rights On Accessibility And Communication Based On Undang-Undang Nomor 8 Tahun 2016 Concerning Disabilities. Indonesian Journal of Disability Studies (IJDS).2018: Vol. 5(2): PP 268-295. 
Bahasa Isyarat bagi orang Tuli, sehingga hak tersebut dilembagakan pada Pasal 24 huruf c. Pasal tersebut menegaskan bahwa orang Tuli memiliki hak untuk menggunakan dan memperoleh fasilitas informasi dan komunikasi berupa Bahasa Isyarat. Bahkan terdapat larangan bagi setiap orang yang menghalanghalangi dan/atau melarang orang Tuli untuk dapat menggunakan dan memperoleh fasilitas berupa Bahasa Isyarat. ${ }^{41}$

Sehubungan dengan hal tersebut di atas, muncul pertanyaan, apakah hak atas komunikasi berupa Bahasa Isyarat telah diperoleh oleh orang Tuli? Berdasarkan hasil wawancara dengan orang-orang Tuli di Yogyakarta, peneliti menemukan bahwa terdapat dua kondisi yang berbeda yang dialami oleh orang Tuli. Disatu sisi terdapat beberapa orang Tuli yang sudah mendapatkan akses terhadap hak atas komunikasi berupa Bahasa Isyarat, dan disisi lain terdapat beberapa orang yang dalam berkomunikasi masih mengandalkan membaca gerak bibir (lipreading), bahasa lisan (oral) dan tulisan.

\section{Kondisi Pertama}

Muhammad Erwin Althaf mengakui bahwa Bahasa Isyarat merupakan hal yang penting bagi seorang Tuli dalam berkomunikasi, terutama komunikasi antar orang Tuli. Namun hal tersebut tidak berlaku apabila dirinya bertemu dan menjalin komunikasi dengan orang dengar. Dalam kesehariannya, Althaf sering menggunakan bahasa lisan untuk berkomunikasi dengan orang dengar, sedangkan dengan orang Tuli, Althaf hanya menggunakan tulisan dan bukan Bahasa Isyarat. ${ }^{42}$

Meskipun Althaf mengakui bahwa Bahasa Isyarat itu penting, Althaf sangat jarang sekali menggunakan Bahasa Isyarat, melainkan lebih suka menggunakan tulisan dan bahasa lisan. Kondisi tersebut dipengaruhi oleh kegiatan belajar mengajar selama ia mengenyam pendidikan di sekolah umum. Semenjak Sekolah Dasar sampai dengan Sekolah Mengenah Atas, Althof tidak pernah diajari menggunakan Bahasa Isyarat, melainkan lebih kepada bahasa lisan yang mengandalkan lipreading maupun tulisan. Oleh karena itu, semenjak duduk di bangku sekolah sampai

\footnotetext{
41 Lihat Pasal 143 UU No. 8 Tahun 2016 tentang Penyandang Disabilitas.

${ }^{42}$ Berdasarkan hasil wawancara dengan Muhammad Erwin Althaf, tertanggal 18 September 2018.
}

dengan sekarang, Althaf lebih terbiasa untuk berkomunikasi menggunakan bahasa lisan, dan tulisan. $^{43}$

Hal yang sama juga dialami oleh Mukhanif Yasin Yusuf. Selama ini Yusuf berkomunikasi dengan orang lain dengan membaca gerak bibir. Apabila terdapat beberapa hal yang tidak dimengerti, Yusuf dan lawan bicaranya akan menggunakan tulisan untuk memperjelas pesan yang disampaikan dalam proses komunikasi tersebut. Jarang sekali Yusuf menggunakan Bahasa Isyarat untuk berkomunikasi, baik itu dengan orang dengar maupun orang Tuli. ${ }^{44}$ Althaf maupun Yusuf sama-sama menyatakan bahwa mempelajari Bahasa Isyarat cukup sulit, sehingga keduanya sampai sekarang belum mahir untuk menggunakannya. ${ }^{45}$

Apabila ditelusuri lebih jauh, penyebab kondisi Althaf dan Yusuf - yang tidak menggunakan Bahasa Isyarat - ialah karena keduanya tidak bergabung dalam komunitas Tuli. Selama ini interaksi yang terbangun antara Althaf dan Yusuf dengan lingkungan sekitar ialah hanya dengan orang dengar. Dengan demikian keduanya telah dipengaruhi dengan budaya dengar.

Perlu dikemukakan bahwa budaya orang dengar dan budaya orang Tuli sangat berbeda. Perbedaan tersebut dapat dijelaskan sebagai berikut. Orang dengar dalam berkomunikasi akan lebih banyak mengandalkan kemampuan mendengarnya, dan berkomunikasi menggunakan bahasa lisan. Hal ini berbeda dengan orang Tuli yang selalu menggunakan kemampuan visual untuk melihat lawan bicaranya mengisyaratkan sesuatu hal dalam proses komunikasi. Sehubungan dengan itu, seorang Tuli ketika berkomunikasi tidak dapat dilakukan di tempat yang cahayanya redup, karena orang Tuli harus melihat ekspresi maupun gerakan tangan yang diisyaratkan pihak lain. Sedangkan untuk orang dengar, komunikasi dapat dilakukan dimana saja, baik itu dalam keadaan cahaya yang terang, redup, bahkan gelap sekalipun - karena yang dibutuhkan orang dengar hanyalah suara. Untuk lebih jelasnya, perbedaan antara orang Tuli dan orang dengar dapat dilihat pada tabel berikut ini.

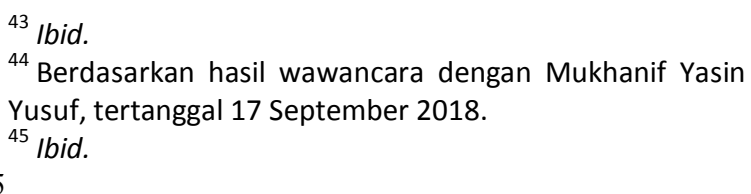

Luhulima, Hendro Valence. Implementation Of Devotional Rights On Accessibility And Communication Based On Undang-Undang Nomor 8 Tahun 2016 Concerning Disabilities. Indonesian Journal of Disability Studies (IJDS).2018: Vol. 5(2): PP 268-295. 
Tabel 1. Perbedaan Budaya Tuli dan Dengar ${ }^{46}$

\begin{tabular}{|l|l|}
\hline \multicolumn{1}{|c|}{ Budaya dengar } & \multicolumn{1}{c|}{ Budaya Tuli } \\
\hline Oral-aural & Visual-motor \\
\hline Tepuk tangan & Lambai tangan \\
\hline Bel suara & Bel lampu \\
\hline Tempat redup & Tempat terang \\
\hline Panggilan nama & Nama isyarat \\
\hline $\begin{array}{l}\text { Tidak perlu bertatap } \\
\text { mata }\end{array}$ & Bertatap mata \\
\hline $\begin{array}{l}\text { Tidak dapat } \\
\text { berbicara dengan } \\
\text { mulut penuh } \\
\text { makanan tidak } \\
\text { sopan) }\end{array}$ & $\begin{array}{l}\text { Dapat dengan mulut penuh } \\
\text { makanan }\end{array}$ \\
\hline \multicolumn{2}{|l}{} \\
\hline
\end{tabular}

Berdasarkan penjelasan di atas, yang ingin disampaikan ialah bahwa perilaku dan konsep berpikir seseorang yang tergabung dalam komunitas tertentu akan sangat dipengaruhi oleh nilai-nilai budaya yang dianut oleh komunitas tersebut. ${ }^{47} \mathrm{~J}$. Berry lewat tulisannya yang berjudul "Social and Cultural Change" mengatakan bahwa identitas budaya memberikan kerangka acuan untuk bagaimana individu mendefinisikan diri mereka, dan menata hubungan sosial individu tersebut. ${ }^{48}$ Dengan adanya hal ini ketika seorang Tuli berada di komunitas Tuli, identitas orang Tuli tersebut dibangun sesuai budaya Tuli. Begitupula sebaliknya, apabila berada dalam lingkungan orang dengar, orang Tuli tersebut akan mengikuti, baik secara terpaksa maupun sukarela $^{49}$ dengan budaya orang dengar. Hal ini

\footnotetext{
${ }^{46}$ Adhi Kusumo Bharoto, "Identitas dan Budaya Tuli" Loc. Cit.

${ }^{47}$ Hermine H. Marshall, "Cultural Influences on the Development of Self-Concept: Updating our thinking", Young Children, Volume 56, Nomor 5, 2001, hlm. 19.

$48 \mathrm{~J}$. Berry, 1980, Social and cultural change dalam William B. Gudykunst dan Tsukasa Nishida, "The Influence of Culture and Strength of Cultural Identity on Individual Values in Japan and the United States", Intercultural Communication Studies, Volume 9, Nomor 1, 2000, hlm. 6.

${ }^{49}$ Dikatakan secara terpaksa apabila orang Tuli tersebut tidak merasa nyaman dengan lingkungan sekitar yang mengharuskannya, contoh, menggunakan bahasa lisan dalam berkomunikasi. Pada tataran ini, nilai individu orang Tuli tersebut yang dipegang kuat daripada nilai kelompok. Berkaitan dengan hal tersebut Gudykunst dan Nishida mengatakan bahwa orang yang mengidentifikasi dirinya dengan sangat kuat dengan menjadi anggota kelompok tertentu ialah karena nilai-nilai individual orang tersebut konsisten dengan nilai budaya kelompok. Sementara orang-orang yang merasa lemah dengan menjadi bagian dari kelompok tertentu ialah karena orang yang bersangkutan memegang beberapa nilai
}

terbukti dengan keberadaan Althaf dan Yusuf, di mana keduanya tidak menggunakan Bahasa Isyarat sebagai identitas orang Tuli, melainkan lebih memilih menggunakan bahasa lisan karena selama ini mereka hidup dan dibesarkan dengan budaya orang dengar.

\section{Kondisi Kedua}

Berbeda dengan kedua responden di atas, Adhi Darmawan, Zhulfi Bajra, Fayza Putri Adila, Nadya Putri, dan Hestu Wijayasri lebih banyak berinteraksi dengan orang Tuli, sebab kelima responden tersebut tergabung dalam komunitas Tuli. Implikasinya, kelima responden ini lebih memilih untuk menggunakan Bahasa Isyarat ketika berkomunikasi dengan sesama Tuli, sedangkan dengan orang dengar mereka akan menggunakan tulisan ${ }^{50}$, bahasa lisan ${ }^{51}$, Bahasa Isyarat ataupun menggabungkan ketiganya ${ }^{52}$.

Apabila membandingkan kondisi pertama dan kondisi kedua, komunikasi antara orang Tuli dan orang dengar sama-sama menggunakan tulisan maupun bahasa lisan. Namun perbedaannya ialah pada kondisi kedua, responden di sela-sela komunikasi tersebut juga memasukan atau mengajarkan Bahasa Isyarat kepada orang dengar. Harapannya agar orang dengar dapat sedikit demi sedikit menggunakan Bahasa Isyarat, bahkan akan lebih baik jika orang dengar dapat menguasai Bahasa Isyarat.

Terdapat sebuah anekdot bahwa semua orang Tuli dapat berbincang-bincang semalam suntuk apabila menggunakan Bahasa Isyarat. Namun hal tersebut tidak berlaku jika orang Tuli diharuskan untuk menggunakan bahasa lisan dan membaca gerak bibir. Bagi orang Tuli hal tersebut sangat sulit dan melelahkan. Keadaan ini juga dirasakan oleh kelima responden pada kondisi kedua. Permasalahan utamanya ialah kelancaran komunikasi.

Berdasarkan penuturan Phieter Angdika selaku ketua Gerakan untuk Kesejahteraan Tunarungu Indonesia (Gerkatin) Kepemudaan, selama ini orang Tuli dipaksakan untuk dapat

individual yang tidak konsisten dengan nilai-nilai budaya kelompok tersebut. Lihat Ibid., hlm. 2.

${ }^{50}$ Zhulfi Bajra, dan Nadya Putri hanya menggunakan tulisan untuk berkomunikasi dengan orang dengar.

${ }^{51}$ Hastu Wijayasari hanya menggunakan bahasa lisan untuk berkomunikasi dengan orang dengar.

${ }^{52}$ Adhi Hermawan, dan Fayza Putri Adila menggunakan bahasa lisan, maupun tulisan ketika berkomunikasi dengan orang dengar.

Luhulima, Hendro Valence. Implementation Of Devotional Rights On Accessibility And Communication Based On Undang-Undang Nomor 8 Tahun 2016 Concerning Disabilities. Indonesian Journal of Disability Studies (IJDS).2018: Vol. 5(2): PP 268-295. 
berbicara atau menggunakan bahasa lisan. ${ }^{53}$ Persepsi yang dibangun selama ini terhadap orang Tuli adalah bahwa berkomunikasi menggunakan Bahasa Isyarat akan menghambat kemampuan orang Tuli untuk berbicara, ${ }^{54}$ oleh karena itu orang Tuli harus dilatih berkomunikasi menggunakan bahasa lisan terus-menerus.

Edwark Dolnick menegaskan bahwa belajar berbicara sangat sulit bagi orang Tuli khususnya yang terlahir Tuli - karena ia mencoba untuk berbicara tanpa umpan balik langsung dan meniru suara yang belum pernah ia dengar sebelumnya ${ }^{55} \mathrm{Hal}$ ini berbeda dengan orang dengar yang menjadi Tuli - karena penyakit, kecelakaan - di mana ia pernah mempunyai pengalaman mendengar kata-kata yang ia pelajari sebelumnya. ${ }^{56}$ Selain dipaksakan untuk berbicara, orang Tuli juga mau tidak mau harus membaca gerak bibir lawan bicaranya. ${ }^{57}$ Lip-reading (kadang-kadang disebut speech reading) adalah keterampilan yang sulit diperoleh. Bahkan lip-readers terbaik hanya dapat menangkap 25\% - 30\% dari apa yang dikatakan oleh orang lain. Persentase ini mungkin akan sedikit lebih tinggi apabila orang Tuli mengenal lawan bicaranya dengan baik. Kendati demikian, banyak gerakan mulut tampak serupa di bibir dan mungkin terlihat sama bagi orang Tuli. ${ }^{58}$

Keadaan-keadaan sebagaimana di sebutkan di atas - berbicara, dan lip-reading - terlihat sangat jelas ketika orang Tuli berada di sekolah, maupun di rumah. Sebagai contoh para responden pada penelitian ini di mana semuanya berasal dari keluarga dengar atau memiliki orang tua dengar. Orang tua tersebut dalam kesehariannya berkomunikasi dengan anaknya yang Tuli tidak menggunakan Bahasa Isyarat, melainkan menggunakan bahasa lisan, dan tulisan. Sehubungan dengan keadaan

\footnotetext{
53 Berdasarkan hasil wawancara dengan Phieter Angdika, tertanggal 29 Agustus 2018.

${ }^{54}$ Disability Unit, "Myths and Misconceptions about Deaf People",

http://www.cput.ac.za/blogs/disability/disabilityawareness/deaf-hearing-impairment-info/myths-andmisconceptions-about-deaf-people/, diakses 24 September 2018.

55 Edwardk Dolnick, "Deafness as culture", The Atlantic, Volume 272, Nomor 3, 1993, hlm.39.

56 Ibid.

${ }^{57}$ Berdasarkan hasil wawancara dengan Muhammad Diki Prasetyo, tertanggal 9 Juni 2018.

${ }^{58}$ Disability Unit, Loc. Cit.
}

tersebut muncul pertanyaan, apa yang menjadi penyebab sehingga orang tua dari para responden ini tidak menggunakan Bahasa Isyarat? Pertanyaan ini muncul sebab peneliti menemukan suatu keanehan. Alasannya karena bukan hanya orang tua dari responden Tuli yang tidak bergabung dengan komunitas Tuli saja yang tidak menggunakan Bahasa Isyarat, melainkan orang tua dari responden Tuli yang telah bergabung dengan komunitas Tuli juga melakukan hal yang sama.

Sebagaimana telah dijelaskan sebelumnya bahwa identitas orang Tuli yang tergabung dalam komunitas Tuli adalah menggunakan Bahasa Isyarat. Konsekuensinya, orang tua dari orang Tuli tersebut juga akan terpengaruh untuk menggunakan Bahasa Isyarat ketika berkomunikasi dengan anaknya. Setidaknya orang tua tersebut menggunakan Bahasa Isyarat dalam frekuensi yang sedang. Namun berdasarkan penelitian di lapangan, hal tersebut tidak terjadi. Para responden juga tidak memberikan jawaban yang pasti terhadap pertanyaan peneliti. Meskipun demikian, berdasarkan penelusuran pustaka yang dilakukan oleh peneliti, ditemukan bahwa kondisi sebagaimana disebutkan sebelumnya terjadi karena selama ini terdapat perbedaan pandangan dari orang tua dengar terhadap anaknya yang Tuli. Adapun pandangan yang dimaksud dapat dijelaskan sebagai berikut.

a. Medical-disability model

Medical-disability model mendefenisikan Tuli sebagai kondisi patologis, di mana terdapat kegagalan dalam mekanisme pendengaran. Tuli diartikan sebagai kondisi medis yang membutuhkan semacam remediasi. Model ini menghendaki seorang Tuli untuk berbicara, mendengar, dan membaca gerak bibir berdasarkan pada asumi bahwa kompetensi dalam bahasa lisan adalah sarana yang diingankan untuk perkembangan kongnitif dan komunikasi. $^{59}$

\section{b. Socio-cultural model \\ Socio-cultural model memiliki pandangan yang berbeda dengan}

59 Bernadette Chapman, 2008, Deafness and Mental Health: Guidelines for Working with People who are Deaf or Hard of Hearing, Queensland: Queensland Health, hlm. 9 .

Cite this as:

Luhulima, Hendro Valence. Implementation Of Devotional Rights On Accessibility And Communication Based On Undang-Undang Nomor 8 Tahun 2016 Concerning Disabilities. Indonesian Journal of Disability Studies (IJDS).2018: Vol. 5(2): PP 268-295. 
medical-disability model. Model ini memandang orang Tuli sebagai kelompok budaya yang memiliki ciri khas khusus dan tertentu, seperti kebutuhan, pendapat, kebiasaan, dan bahasa mereka sendiri. Anggota komunitas Tuli mendefinisikan Tuli sebagai istilah budaya daripada istilah audiologis (audiological term). Sociocultural model mengakui perbedaan sosio-linguistik yang signifikan antara orang-orang yang melabeli diri Tuli dan orang-orang yang menyebut diri mereka sulit mendengar (hard of hearing). ${ }^{60}$

Apabila melihat kedua pandangan di atas, pandangan pertama lebih banyak dianut, terutama orang tua dengar yang memiliki anak Tuli sejak lahir. Hal ini juga cocok untuk menggambarkan keadaan orang tua dari para responden penelitian ini. Orang tua tersebut sering mengidentifikasi Tuli dengan budaya orang dengar, dan juga melihat gangguan pendengaran dalam medical-disability model. Oleh karena itu, apabila dipaksa sekalipun untuk berkomunikasi menggunakan Bahasa Isyarat, orang tua dengar tersebut tidak akan mau. ${ }^{61}$ Hal ini perlu diubah, sebab apabila orang Tuli masih dipaksakan melakukan sesuatu yang sesuai dengan budaya dengar, maka ia akan merasa tertekan dan seolah-oleh disingkirkan dari lingkungan sosial. Sehubungan dengan itu, Macurová dalam Martin Vaněk menegaskan bahwa orang Tuli tidak seharusnya bergantung pada bahasa lisan, sebab dalam pengamatannya, orang Tuli tidak mampu untuk memahami bahasa lisan sekalipun diberikan alat bantu dengar. $^{62}$

Perlakuan yang mengidentifikasi Tuli dengan budaya orang dengar ini dapat

\footnotetext{
60 Ibid.

61 Peneliti menyadari bahwa kesimpulan yang dikemukakan ini tidak didahului dengan penelusuran secara langsung kepada orang tua yang memiliki anak Tuli, melainkan hanya berdasarkan dugaan peneliti yang dikuatkan dengan penelusuran pustaka. Oleh sebab itu, mengenai hal ini dapat dan perlu untuk diteliti lebih lanjut, karena bisa jadi faktor lain yang menyebabkan orang tua tidak menggunakan Bahasa Isyarat ialah karena faktor pengetahuan, maupun sulitnya Bahasa Isyarat karena tidak diperkenalkan sejak awal.

62 Lihat Martin Vaněk, 2009, Language Learning and Deafness, Desertasi, Faculty of Education Department of English Language and Literature Masarykova Univerzita, Brno, Ceko, hlm. 15-16.
}

dikatakan termasuk dalam upaya untuk melarang atau menghalang-halangi orang Tuli mengakses budaya mereka sendiri yaitu menggunakan Bahasa Isyarat. Di dalam Pasal 143 UU No. 8 Tahun 2016 tentang Penyandang Disabilitas telah secara jelas menegaskan bahwa setiap orang dilarang menghalanghalangi dan/atau melarang orang Tuli untuk mendapatkan hak berkeskpresi, berkomunikasi, dan memperoleh informasi berupa Bahasa Isyarat. Apabila ada yang melanggar ketentuan tersebut, dapat dipidana dengan pidana penjara paling lama dua tahun dan denda paling banyak Rp 200.000.000,00, sesuai dengan ketentuan Pasal 145. Namun, apabila melihat kondisi yang ada, sampai dengan saat ini pelanggaran akan Pasal 143 tersebut tidak pernah ditindaklanjuti dan dijatuhi sanksi sebagaimana dimaksud Pasal 145. Padahal dengan adanya tindakan tegas dari Pemerintah dapat menjadi salah satu bukti yang menguatkan posisi Pemerintah untuk membela hak-hak orang Tuli. Terlebih lagi Pemerintah Indonesia telah berjanji untuk menghormati dan menjamin hak asasi yang dimiliki oleh setiap orang yang berada dalam wilayah negaranya - termasuk orang Tuli tanpa pembedaan apapun. ${ }^{63}$ Semua ini dilakukan dengan maksud agar orang Tuli mendapatkan kesetaraan dalam pelaksanaan dan pemenuhan hak-haknya. ${ }^{64}$

Dalam rangka mengubah cara berpikir yang salah dari orang tua dengar atas anak Tuli, Pemerintah Indonesia perlu membuat sebuah program khusus untuk mengedukasi dan mengadvokasi pentingnya pengajaran Bahasa Isyarat kepada anak Tuli sejak dini. Program ini diharapkan dapat membentuk identitas dan karakter anak Tuli, terutama perasaan bangga anak tersebut sebagai Tuli. Disamping itu, tujuan akhirnya sebenarnya untuk membangun hubungan yang akrab dan harmonis antara

\footnotetext{
63 Janji sebagaimana disebutkan pada bagian ini merupakan konsekuensi dari disahkannya ICCPR melalui Undang-Undang Nomor 12 Tahun 2005 tentang Pengesahan International Covenant on Civil and Political Rights (Kovenan Internasional tentang Hak-Hak Sipil dan Politik). Janji ini dapat dilihat pada Pasal 2 ICCPR.

64 Lihat Pasal 2 UU No. 8 Tahun 2016 yang mengamanatkan bahwa pelaksanaan dan pemenuhan hak Penyandang Disabilitas berasaskan kesetaraan. Kesetaraan diartikan sebagai kondisi di berbagai sistem dalam masyarakat dan lingkungan, seperti pelayanan, kegiatan, informasi, dan dokumentasi yang dibuat dapat mengakomodasi semua orang termasuk Penyandang Disabilitas, secara khusus orang Tuli.
}

Luhulima, Hendro Valence. Implementation Of Devotional Rights On Accessibility And Communication Based On Undang-Undang Nomor 8 Tahun 2016 Concerning Disabilities. Indonesian Journal of Disability Studies (IJDS).2018: Vol. 5(2): PP 268-295. 
orang tua dengan anak Tuli, ketika keduanya dapat berkomunikasi dengan satu bahasa yang dapat dimengerti oleh semuanya.

Di Australia, Pemerintah sudah lebih fokus kepada orang Tuli secara khusus pada masa anak Tuli lahir sampai usia sekolah. Pemerintah Australia bekerja sama dengan Deaf Australia Inc untuk merancangkan sebuah program yang disebut Early Intervention Program, yang ditujukan untuk orang tua yang mempunyai anak Tuli. Program ini dimaksudkan untuk mengadvokasi dan mendukung orang tua dalam mengajarkan kemampuan berkomunikasi baik itu bahasa lisan (Bahasa Inggris), maupun Bahasa Isyarat Australia atau yang disebut dengan Auslan secara seimbang. Program ini akan membantu orang tua untuk lebih dekat dengan anak Tuli, dan mengenal apa yang terbaik bagi anak Tuli kedepannya.

Program early intervention ini bukan hal yang baru, melainkan sudah pernah dijalankan di Australia. Namun program-program sebelumnya hanya berfokus untuk mengembangkan bahasa lisan kepada anak Tuli karena komunikasi dengan bahasa lisan dianggap sebagai satu-satunya hal yang terbaik. Program tersebut dipengaruhi oleh pandangan medis yang mengganggap Tuli itu harus diperbaiki/disembuhkan, sehingga kebanyakan progam early intervention hanya menyediakan akses ke bahasa lisan saja. Berangkat dari kondisi tersebut, Deaf Australia Inc berpendapat bahwa pendekatan tersebut tidak tepat, tidak memadai, dan berpotensi merusak anak, terutama hal ini tidak mendorong untuk terciptanya hubungan keluarga yang sehat. ${ }^{65}$

Menariknya dari kebijakan Pemerintah Australia ini terdapat parent support groups yang dibuat untuk mengawal pelaksanaan program intervensi dini yang telah dilakukan. Pada kelompok ini para orang tua dapat saling mendukung satu sama lain dan berbagi pengalaman untuk mengatasi setiap hambatan dalam pelaksanaan program Pemerintah Australia untuk orang Tuli. ${ }^{66}$ Selain itu, Pemerintah Australia juga menyediakan berbagai portal web yang memberikan informasi secara khusus kepada orang tua sehubungan dengan anak Tuli, misalnya

\footnotetext{
${ }^{65}$ Karen Lloyd, 2009, Policy on Early Intervention for Deaf and Hard of Hearing Children, Deaf Australia Inc, Australia, hlm. 2.

66 Ibid., hlm. 11.
}

http://www.aussiedeafkids.org.au/;

dan https://www.hearing.com.au/. ${ }^{67}$

Adanya praktik terbaik dari Pemerintah Australia ini diharapkan dapat menjadi contoh bagi Pemerintah Indonesia untuk mempromosikan, dan mendukung penggunaan Bahasa Isyarat sejak dini bagi anak-anak Tuli. Peneliti berpendapat bahwa program ini akan memiliki dampak positif untuk pertumbuhan dan perkembangan anak Tuli, apalagi fokus utamanya sejak awal ialah komunikasi. Hak atas komunikasi ini yang akan menjadi pintu masuk bagi pemenuhan hak-hak orang Tuli yang lain. Kendati demikian, perlu dicatat bahwa komunikasi yang diinginkan oleh orang Tuli dan sesuai amanat UU No. 8 Tahun 2016 ialah komunikasi berupa Bahasa Isyarat, sebagai bahasa utama dalam menyampaikan pesan dari satu orang ke orang yang lain.

Sehubungan dengan hal tersebut di atas, Patrick J Brice dan Gillie Strauss menegaskan bahwa kegagalan untuk mengakses hak atas komunikasi, secara tidak langsung telah menghalangi anak Tuli mendapatkan kesempatan yang sah untuk belajar dan memahami orang lain. Akibatnya, beberapa remaja Tuli harus berusaha keras untuk menginternalisasi model perilaku yang patut, mempelajari strategi pengaturan diri, dan bahkan sering salah dalam memahami norma sosial. ${ }^{68}$ Oleh karena itu, komunikasi menggunakan Bahasa Isyarat penting di dorong mulai dari lingkup keluarga, sebab ketika keluarga tidak dapat berkomunikasi secara efektif dengan anak Tuli, hubungan keluarga bahkan lingkungan juga akan terpengaruh.

Phieter Angdika merupakan salah satu contoh anak Tuli yang tidak banyak berkomunikasi dengan orang tuanya. Kendala terbesarnya ialah bahasa. Selama ini Angdika berkomunikasi dengan orang tua hanya sebatas menanyakan kabar, "mau pergi kemana", "jangan pulang malam", "sudah mandi", dan sejenisnya. Itu pun tidak menggunakan Bahasa Isyarat. Angdika tidak pernah bercerita mengenai permasalahannya, atau topik-topik lainnya yang biasa dibicarakan antara anak dengar dengan orang tuanya. Atau dengan kata lain, Angdika tidak pernah berkomunikasi

\footnotetext{
${ }^{67}$ Ibid., hlm. 3.

${ }^{68}$ Patrick J Brice dan Gillie, "Deaf Adolescents in a Hearing World: A Review of Factors Affecting Physchosocial Adaption", Adolescent Health, Medicine and Therapeutics, Volum 7, April 2016, hlm. 68.
}

Luhulima, Hendro Valence. Implementation Of Devotional Rights On Accessibility And Communication Based On Undang-Undang Nomor 8 Tahun 2016 Concerning Disabilities. Indonesian Journal of Disability Studies (IJDS).2018: Vol. 5(2): PP 268-295. 
dengan orang tuanya dalam jangka waktu yang lama. ${ }^{69}$ Pada kondisi ini fungsi komunikasi ekspresif sebagaimana dikemukakan oleh Wiliam I. Gorden tidak terpenuhi. Komunikasi yang seharusnya dijadikan sebagai sarana untuk menyampaikan perasaan (emosi) ${ }^{70}$ tidak dilakukan oleh orang Tuli. Kalaupun disampaikan, pesan tersebut tidak akan diterima dengan baik oleh orang lain, in casu orang tua. Alhasil komunikasi tersebut gagal.

Permasalahan yang di alami Angdika perlu dicegah dan dihindari. Sebagian besar keluarga dengan anak Tuli adalah keluarga dengar $>95 \%$ anak Tuli lahir dari orang tua dengar ${ }^{71}$ dan tidak secara otomatis memiliki bahasa umum yang mudah dibagikan dan memungkinkan komunikasi terjadi secara alami. Hal ini dikarenakan bahasa keluarganya adalah Bahasa Indonesia, dan keluarga diberitahu bahwa anak Tuli memiliki potensi untuk belajar berbicara. ${ }^{72}$ Dengan informasi seperti ini banyak keluarga lebih memilih opsi bahasa lisan daripada Bahasa Isyarat atau bilingual. Untuk itu, perlu ada campur tangan Pemerintah secara aktif dalam memperkenalkan penggunaan Bahasa Isyarat sejak dini kepada anak Tuli, seperti yang dilakukan oleh Pemerintah Australia. Kendati demikian, program Pemerintah Australia ini memiliki kelemahan, yaitu dukungan orang tua dan anggota keluarga lainnya untuk belajar Bahasa Isyarat tidak tersedia secara meluas atau di danai. Hal ini berbeda dengan Swedia yang menyediakan program pembelajaran Bahasa Isyarat bagi orang tua yang memiliki anak Tuli sejak dini, dan membiayai program tersebut secara penuh. ${ }^{73}$

Melengkapi kekurangan Pemerintah, Dewan Pengurus Pusat (DPP) Gerkatin

\footnotetext{
${ }^{69}$ Berdasarkan hasil wawancara dengan Phieter Angdika, tertanggal 29 Agustus 2018.

70 Deddy Mulyana, 2008, IImu Komunikasi Suatu Pengantar, Bandung: Remaja Rosdakarya, hlm. 24.

${ }^{71}$ Nancy K. Mellon, et al., "Should All Deaf Children Learn Sign Language?", Pediatrics, Volume 135, Nomor 1, Juli 2015, hlm. 171.

${ }^{72}$ Perlu diakui bahwa memang terdapat beberapa orang Tuli yang dapat berbicara bahasa lisan, namun pada umumnya anak Tuli akan lebih lama untuk dapat berbicara bahasa lisan secara lancar daripada Bahasa Isyarat. Alasannya karena Bahasa Isyarat dapat diakses sepenuhnya oleh anak Tuli, sedangkan bahasa lisan hanya diakses sebagian tergantung tingkat ketulian anak tersebut.

${ }^{73}$ Karen Lloyd, Op. Cit., hlm. 17.
}

membentuk sebuah lembaga yang berfungsi untuk mempromosikan dan mendorong penggunaan Bahasa Isyarat Indonesia untuk orang Tuli. Lembaga tersebut bernama Pusat Bahasa Isyarat Indonesia (Pusbisindo). Sejak didirikan pada tahun 2009 silam, Pusbisindo gencar memperkenalkan Bahasa Isyarat Indonesia ${ }^{74}$ kepada masyarakat dengan membuka Kelas Bahasa Isyarat di berbagai daerah, salah satunya yaitu di Yogyakarta. Di Yogyakarta, Kelas Bahasa Isyarat sudah mencapai angkatan ketiga. Peserta dari kelas ini meliputi karyawan, masyarakat umum, dan mahasiswa, baik itu orang Tuli maupun orang dengar yang memiliki ketertarikan untuk mengenal lebih jauh tentang budaya orang Tuli. $^{75}$

\subsection{Hak atas Aksesibilitas}

Pemaknaan "aksesibilitas" dalam UU No. 8 Tahun 2016 sudah sangat jelas bahwa aksesibilitas adalah kemudahan yang disediakan bagi Penyandang Disabilitas untuk

\footnotetext{
${ }^{74}$ Berdasarkan penuturan dari Ketua Pusat Layanan Juru Bahasa Isyarat Indonesia, Juniati Effendi, pembentukan Pusbisindo selain untuk mengadvokasi penggunaan Bahasa Isyarat melainkan juga sebagai bentuk protes atas Sistem Isyarat Bahasa Indonesia (SIBI) yang diperkenalkan oleh Pemerintah. Rini Kustiani, "Pusbisindo, Cara Unik Belajar Bahasa Isyarat",
} https://difabel.tempo.co/read/1109916/pusbisindo-caraunik-belajar-bahasa-isyarat, diakses 9 Oktober 2018. Lihat juga Damaiati R. Kurnia dan Thohari Slamet, "Menormalkan yang Dianggap Tidak Normal (Studi Kasus Penerbitan Bahasa Isyarat Tunarungu di Sekolah Luar Biasa (SLB) dan Perlawanannya di Kota Malang", Indonesian Journal of Disability Studies, Volume 3, Nomor 1, 2016, hlm. 41-42. SIBI secara sederhana diartikan sebagai Bahasa Isyarat yang pembacaannya mengacu pada Bahasa Indonesia lisan. Pembuatan SIBI juga tidak melibatkan orang-orang Tuli di dalamnya, melainkan hanya mengubah Bahasa Indonesia lisan menjadi Bahasa Isyarat dan kosa katanya banyak diambil dari Bahasa Isyarat Amerika. Itulah mengapa orang Tuli dan komunitasnya menganggap bahwa SIBI bukan merupakan sebuah Bahasa Isyarat, melainkah hanya sistem isyarat. Dikarenakan hanya merupakan sebuah sistem isyarat, mempelajari SIBI sangat sulit bagi orang Tuli. Sehubungan dengan itu, Nick Palfreyman dalam tulisannya yang berjudul Budaya Tuli dan Hak Bahasa menyampaikan pendapatnya bahwa grammar SIBI yang mengikuti tata Bahasa Indonesia mudah dipelajari oleh guru dan orang tua dengar, tetapi hal ini sangat sulit bagi orang Tuli yang belum pernah mendengar Bahasa Indonesia. Nick Palfreyman, Op. Cit., hlm. 5.

${ }^{75}$ Berdasarkan hasil wawancara dengan Muhammad Diki Prasetyo selaku Koordinator Pusat Bahasa Isyarat Indonesia Yogyakarta, tertanggal 9 Oktober 2018. 280

Cite this as:

Luhulima, Hendro Valence. Implementation Of Devotional Rights On Accessibility And Communication Based On Undang-Undang Nomor 8 Tahun 2016 Concerning Disabilities. Indonesian Journal of Disability Studies (IJDS).2018: Vol. 5(2): PP 268-295. 
mewujudkan kesamaan kesempatan. Kesamaan kesempatan untuk dapat terlibat dalam segala aspek kehidupan dan penghidupan. Dengan demikian, hak atas aksesibilitas penting untuk diberikan kepada Penyandang Disabilitas, in casu orang Tuli.

Aksesibilitas ini tidak hanya berlaku diantara Penyandang Disabilitas dan individu yang bukan Penyandang Disabilitas saja, melainkan juga berlaku antar sesama Penyandang Disabilitas. Mengenai hal yang disebut terakhir penting untuk diberikan penekanan, sebab dewasa ini terdapat indikasi bahwa Pemerintah maupun para pemangku kepentingan lainnya menerapkan kebijakan yang sifatnya diskriminatif diantara Penyandang Disabilitas. Atau dengan kata lain terdapat indikasi diskriminasi berdasarkan disabilitas.

Diskriminasi disabilitas diartikan sebagai pembedaan, pengecualian, atau pembatasan atas dasar disabilitas. Pembatasan atau pengecualian ini dapat ditujukan secara langsung maupun tidak langsung kepada disabilitas tertentu. Diskriminasi secara langsung artinya diskriminasi yang memang dimaksudkan untuk membatasi atau mengecualikan pemenuhan hak Penyandang Disabilitas yang bersangkutan. Sedangkan secara tidak langsung adalah diskriminasi yang berdampak pada pengurangan atau peniadaan pengakuan, penikmatan dan pelaksanaan semua HAM dan kebebasan fundamental. ${ }^{76}$

Keadaan sebagaimana disebutkan di atas dapat terlihat pada beberapa bidang yang akan dijelaskan dibawah ini. Penjabaran ini sekaligus ingin menunjukan apakah hak aksesibilitas telah atau belum diberikan kepada orang Tuli. Adapun beberapa bidang yang menjadi sorotan peneliti yaitu sebagai berikut.

\section{a. Pendidikan}

Di era kontemporer ini, pendidikan masih memegang peranan penting dalam

\footnotetext{
76 Secara sederhana yang membedakan diskriminasi langsung dan tidak langsung adalah tujuan dari pembuatan kebijakan atau perbuatan yang dilakukan. Diskriminasi ini mencakup semua bentuk diskriminasi, termasuk penolakan atas pemberian akomodasi yang patut. Akomodasi yang patut berarti modifikasi dan penyesuaian yang harus dan sesuai, dengan tidak memberikan beban tambahan yang tidak proporsional untuk menjamin penikmatan dan pelaksanaan semua HAM dan kebebasan fundamental berdasarkan kesetaraan Penyandang Disabilitas. Lihat Pasal 2 CRPD.
}

keberlangsungan hidup manusia. Pendidikan dianggap sebagai upaya terencana dalam proses pembimbingan dan pembelajaran bagi individu untuk tumbuh dan berkembang menjadi manusia yang mandiri, bertanggungjawab, berilmu, dan berakhlak mulia. ${ }^{77}$ Negara-negara di dunia pun setuju akan hal tersebut, bahkan dikatakan juga bahwa pendidikan turut mempengaruhi kualitas suatu bangsa. ${ }^{78}$

Sehubungan dengan hal tersebut di atas, setiap individu berhak untuk memperoleh pendidikan ${ }^{79}$ tanpa melihat status, latarbelakang keluarganya, fisik, kesehatan dan sebagainya. Pendidikan harus diarahkan pada perkembangan kepribadian manusia seutuhnya dan kesadaran akan harga dirinya, serta memperkuat penghormatan atas HAM dan kebebasan manusia yang mendasar. ${ }^{80}$ Tentu hal ini menjadi harapan besar bagi setiap orang, terkhusus orang Tuli untuk mengenyam pendidikan yang dapat mengembangkan kualitas dirinya.

Berdasarkan data yang diperoleh dari responden, terdapat dua kondisi yang menggambarkan aksesibilitas orang Tuli dalam dunia pendidikan, yaitu sebagai berikut.

\section{Kondisi Pertama}

Dunia pendidikan tidak luput dari paradoks - pujian semu. Selama ini pendidikan dipujipuji sebagai solusi dari setiap permasalahan yang ada, seperti kemiskinan, keterbelakangan, dan kebodohan. Pendidikan juga seringkali diharapkan dapat bernilai sebagai proses pembelajaran sekaligus pemberdayaan kemampuan dan kesanggupan peserta didiknya. ${ }^{81}$ Namun pada kenyataannya, hal tersebut tidak berlaku bagi orang Tuli.

Berdasarkan penuturan dari sejumlah responden, dikemukakan bahwa kendala terbesar mereka selama mengenyam dunia

\footnotetext{
${ }^{77}$ Naufal IIma, "Peran Pendidikan sebagai Modal Utama Membangun Karakter Bangsa", Tadbir Jurnal Manajemen Pendidikan Islam, Volume 3, Nomor 1, Februari 2015, hlm. 82-83.

${ }^{78}$ Muhardi, "Kontribusi Pendidikan dalam Meningkatkan Kualitas Bangsa Indonesia", Mimbar: Jurnal Sosial dan Pembangunan, Volume 20, Nomor 4, Oktober-Desember 2004, hlm. 480.

${ }^{79}$ Lihat Pasal 26 UDHR.

${ }^{80}$ Lihat Pasal 13 ICESCR.

${ }^{81}$ Nina Siti Salmaniah Siregar, "Persepsi Orang Tua terhadap Penitngnya Pendidikan bagi Anak", Jurnal IImu Pemerintahan dan Sosial Politik, Volume 1, Nomor 1, 2013, hlm. 18-19.
} 
pendidikan ialah bahasa untuk berkomunikasi. Selama ini, sebagian besar pendidik menggunakan bahasa lisan, daripada Bahasa Isyarat. Hal ini tentu menjadi kendala tersendiri bagi orang Tuli untuk dapat memahami dengan baik dan benar materi pelajaran/perkualiahan yang disampaikan. Lebih jauh lagi usaha untuk mewujudkan suasana belajar dan proses pembelajaran agar peserta didik dapat secara aktif mengembangkan potensi dirinya sesuai amanat Undang-Undang No. 20 Tahun 2003 tentang Sistem Pendidikan Nasional tidak akan terwujud.

Komentar Umum No. 5 dari Komite Ekonomi, Sosial dan Budaya PBB tentang Penyandang Disabilitas menegaskan bahwa program pendidikan di banyak negara pada saat ini telah mengakui bahwa para Penyandang Disabilitas dapat diberikan pendidikan yang terbaik melalui sistem pendidikan umum. Indonesia sebagai negara peserta juga menjamin hal yang sama, misalnya lewat Pasal 10 UU No. 8 Tahun 2016 tentang Penyandang Disabilitas. Ketentuan tersebut memberikan jaminan bahwa Penyandang Disabilitas berhak mendapatkan pendidikan yang bermutu pada satuan pendidikan di semua jalur, jenis, dan jenjang pendidikan secara inklusi.

Pendidikan secara inklusi diartikan sebagai pendidikan yang ditujukan bagi peserta didik Penyandang Disabilitas untuk belajar bersamasama dengan peserta didik bukan Penyandang Disabilitas di sekolah regular atau perguruan tinggi. ${ }^{82}$ Ketentuan ini secara tidak langsung mengakui prinsip persamaan, baik di tingkat dasar, lanjutan, maupun menengah bagi anakanak, remaja, maupun orang dewasa yang menyandang disabilitas untuk mengenyam pendidikan dalam pengaturan yang integratif. ${ }^{83}$ Dalam rangka mengimplementasikan pendekatan ini, Pemerintah Indonesia, harus menjamin para pendidik/pengajar terlatih untuk mendidik anak-anak Penyandang Disabilitas dalam sistem sekolah biasa (regular). Selain itu, peralatan dan dukungan yang diperlukan juga harus disediakan bagi Penyandang Disabilitas untuk bisa membawa mereka ke tingkat yang sama sebagaimana rekan-rekannya yang bukan Penyandang Disabilitas. Berkaitan dengan

\footnotetext{
${ }^{82}$ Lihat Penjelasan Pasal 10 UU No. 8 Tahun 2016 tentang Penyandang Disabilitas.

${ }^{83}$ Lihat Paragraf 35 UN Committee on Economic, Social and Cultural Rights (CESCR), General Comment No. 5: Persons with Disabilities, 9 December 1994, E/1995/22.
}

Cite this as:

Luhulima, Hendro Valence. Implementation Of Devotional Rights On Accessibility And Communication Based On Undang-Undang Nomor 8 Tahun 2016 Concerning Disabilities. Indonesian Journal of Disability Studies (IJDS).2018: Vol. 5(2): PP 268-295. kondisi orang Tuli, negara harus mengakui bahwa Bahasa Isyarat sebagai bahasa yang terpisah. Selain itu, negara juga harus memberikan akses bagi orang Tuli atas Bahasa Isyarat yang arti pentingnya harus diakui dalam keseluruhan lingkungan sosial mereka, ${ }^{84}$ termasuk dalam lingkungan pendidikan.

Althaf dan Yusuf merupakan contoh yang tepat untuk menggambarkan bagaimana orang Tuli tidak diberikan aksesibilitas dalam dunia pendidikan. Kedua responden ini menuturkan bahwa ketika masuk pada perguruan tinggi tidak ada suatu layanan atau fasilitas khusus diberikan atau setidaknya ditawarkan kepada orang Tuli selama mengikuti perkuliahan. Fasilitas seperti juru ketik, atau juru Bahasa Isyarat, semua ini tidak disediakan. Kedua responden hanya mengandalkan bantuan dari teman sebangku untuk mencatat materi yang dijelaskan oleh dosen. Selain itu, karena ketiadaan akses yang memadai, mengharuskan keduanya untuk belajar mandiri dan secara proaktif menanyakan kepada dosen mengenai materi yang telah disampaikan di kelas. Apabila kondisi yang dialami oleh Althaf dan Yusuf terjadi secara berulang-ulang kali, tentu akan merepotkan dosen yang bersangkutan, teman, maupun dirinya sendiri. Semua ini dapat terjadi karena aksesibilitas yang seharusnya disediakan Pemerintah lewat perguruan tinggi tidak diberikan sejak awal.

Pada kondisi yang pertama ini, Althaf dan Yusuf tampaknya dapat mengikuti proses perkuliahan dengan baik. Artinya, kedua responden memiliki kemampuan untuk menyeimbangkan posisi mereka dengan temanteman yang lain, meskipun terkadang terhalang oleh beberapa kendala yang harus diselesaikan secara mandiri. Kemampuan yang dimiliki kedua reponden turut dipengaruhi oleh faktorfaktor mereka mengidentifikasi identitas dirinya.

Menurut Baumeister, identitas adalah representasi diri. Diri adalah konstruksi sosial untuk mengembangkan siapa dan apa diri seseorang dengan mengamati dan menafsirkan tanggapan orang lain. Oleh karena itu, pengembangan identitas seseorang adalah proses yang dibangun secara sosial, yang muncul melalui pengalaman dan interaksi masa kini dan masa lalu antara diri sendiri dan

\footnotetext{
${ }^{84}$ Ibid.
} 
lingkungan sosial di sekitarnya. ${ }^{85}$ Secara khusus, apabila seorang Tuli dibesarkan di dalam keluarga dan dididik pada lingkungan sekolah - tempat mereka berinteraksi dengan orang dewasa dan teman sebaya - melalui sarana komunikasi lisan, mereka cenderung dikondisikan oleh budaya dengar. Hal ini terjadi pada kedua responden di atas, karena selama ini mereka tidak pernah terlibat dalam komunitas Tuli, dan komunikasinya tidak menggunakan Bahasa Isyarat. Dengan keadaan ini, orang Tuli tersebut dapat dikatakan sedikit diuntungkan.

Lain halnya dengan seorang Tuli yang tergabung dalam komunitas Tuli tetapi terjebak dalam budaya dengar. Maksudnya ialah, orang Tuli tersebut sejak kecil telah diperkenalkan dengan budaya Tuli lewat penggunaan Bahasa Isyarat. Namun karena tuntutan masa depan ia harus mengikuti pendidikan disekolah atau perguruan tinggi regular - karena tidak ada pendidikan khusus Tuli yang programnya sama dengan pendidikan regular. Angdika merupakan salah satu dari orang Tuli yang mengalami hal tersebut. Pada awalnya Angdika dapat mengikuti materi yang diberikan oleh dosen dengan membaca gerak bibir dosen tersebut. Namun hal ini tidak berlangsung lama, sebab sangat sulit bagi Angdika untuk melakukannya setiap saat. Dikarenakan kondisi tersebut, akhirnya Angdika keluar dari perguruan tinggi tersebut dan pindah ke perguruan tinggi yang lain. Selain Angdika, Zhulfi Bajra juga mengalami hal yang sama, bahkan dipaksa dan ditekan untuk menggunakan bahasa lisan daripada Bahasa Isyarat agar lancar berkomunikasi dengan orang dengar. Hal-hal seperti ini tentu sangat membebani orang Tuli. Prinsip aksesibilitas yang dipromosikan UU No. 8 Tahun 2016 tentang Penyandang Disabilitas hanya sebuah slogan semata. ${ }^{86}$ Perguruan tinggi selalu bersikap terbuka dan tetap memberikan kesempatan yang sama bagi orang Tuli untuk terlibat dalam dunia pendidikan, tetapi seringkali perguruan tinggi

\footnotetext{
${ }^{85}$ Magda Nikolaraizi dan Kika Hadjikakou, "The Role of
Educational Experience in the Development of Deaf

${ }^{85}$ Magda Nikolaraizi dan Kika Hadjikakou, "The Role of
Educational Experience in the Development of Deaf Identity", Journal of Deaf Studies and Deaf Education, Volume 11, Nomor 4, 2006, hlm. 477.

${ }^{86}$ Lihat Pasal 2 huruf h UU No. 8 Tahun 2016 tentang Penyandang Disabilitas.
}

Cite this as:

lupa untuk memberikan kemudahan bagi mereka. $^{87}$

Melihat kondisi pertama ini - terlepas dari keikutsertaan dalam komunitas Tuli atau tidak Pemerintah harus tetap menyediakan fasilitas khusus yang memudahkan orang Tuli untuk berpartisipasi penuh dalam dunia pendidikan. Hal ini perlu dilakukan dalam rangka memberikan kesamaan kesempatan bagi orang Tuli. Pasal $28 \mathrm{H}$ ayat (2) UUD NRI Tahun 1945 menegaskan bahwa setiap orang mempunyai hak atas kemudahan maupun perlakuan khusus untuk memperoleh kesempatan dan manfaat yang sama dalam rangka mencapai persamaan dan keadilan. Hal ini kemudian diperkuat dengan ketentuan Pasal 28 I ayat (2) UUD NRI Tahun 1945 bahwa setiap orang berhak bebas dari perlakuan diskriminatif dengan alasan apapun. Apabila perlakuan diskriminatif itu terjadi, maka ia berhak mendapatkan perindungan atas perlakuan tersebut. Kedua ketentuan ini merupakan dasar hukum yang menjustifikasi bahwa orang Tuli pun berhak menerima perlakuan yang sama dan tidak diskriminatif dengan cara-cara khusus dalam pemenuhan haknya tersebut. Pernyataan ini sejalan dengan tafsiran Mahkamah Konstitusi atas hak konstitusional dalam Pasal $28 \mathrm{H}$ ayat (2) UUD NRI Tahun 1945 melalui Putusan Mahkamah Konstitusi Nomor 143/PUUVII/2009 dan Putusan Mahkamah Konstitusi Nomor 16/PU-VIII/2010. Di dalam kedua putusan tersebut, Mahkamah Konstitusi berpendapat bahwa hak konstitusional dalam Pasal $28 \mathrm{H}$ ayat (2) UUD NRI Tahun 1945 merupakan jaminan konstitusional yang ditujukan kepada mereka yang mengalami peminggiran ketertinggalan, pengucilan, pembatasan, pembedaan, kesenjangan partisipasi dalam politik dan kehidupan publik yang bersumber dari ketimpangan struktural dan sosio-kultural masyarakat secara terusmenerus, baik formal maupun informal, dalam lingkup publik maupun privat. Jaminan ini dikenal dengan affirmative action $^{88}$ atau secara sederhana diartikan sebagai diskriminasi yang positif.

\footnotetext{
${ }^{87}$ Ezza Oktavia Utami, et al., "Aksesibilitas Penyandang Tunadaksa" Prosiding Penelitian dan Pengabdian kepada Masyarakat, Volume 5, Nomor 1, April 2018, hlm. 88.

${ }^{88}$ Aprilina Pawestri, "Hak Penyandang Disabilitas dalam Perspektif HAM Internasional dan HAM Nasional", Era Hukum - Jurnal IImiah IImu Hukum, Volume 2, Nomor 1, Juni 2017, hlm. 177.
} 283

Luhulima, Hendro Valence. Implementation Of Devotional Rights On Accessibility And Communication Based On Undang-Undang Nomor 8 Tahun 2016 Concerning Disabilities. Indonesian Journal of Disability Studies (IJDS).2018: Vol. 5(2): PP 268-295. 


\section{Kondisi Kedua}

Berbeda dengan kondisi pertama, pada kondisi kedua aksesibilitas pada dunia pendidikan mulai dirasakan. Tetapi hal ini tergantung dari kemauan dan kesadaran lembaga pendidikan yang bersangkutan. Universitas Sanata Dharma merupakan salah satu contoh perguruan tinggi yang memberikan kesempatan yang seluas-luasnya bagi orang Tuli untuk dapat mengakses pendidikan di lingkungan perguruan tinggi tersebut. Hal ini dibuktikan dengan disediakannya juru Bahasa Isyarat maupun juru ketik bagi orang Tuli selama mengikuti perkualiahan maupun ujian. ${ }^{89}$

Menurut hemat penulis, ketersediaan fasilitas khusus ini dikarenakan pada perguruan tinggi tersebut telah ada Unit Layanan Disabilitas yang dibentuk untuk mendukung pemenuhan hak-hak Penyandang Disabilitas. Di Universitas Sanata Dharma, Unit Layanan Disabilitas yang dimaksud bernama Pusat Studi Individu Berkebutuhan Khusus (PSIBK). Pembentukan Layanan Disabilitas ini telah sesuai dengan amanat Pasal 42 ayat (3) UU No. 8 Tahun 2016 tentang Penyandang Disabilitas, yaitu pembentukan Unit Layanan Disabilitas wajib difasilitasi oleh setiap penyelenggara pendidikan tinggi. Hal yang sama juga ditegaskan dalam Pasal 10 Peraturan Menteri Riset, Teknologi, dan Pendidikan Tinggi Nomor 46 Tahun 2017 tentang Pendidikan Khusus ${ }^{90}$ dan Pendidikan Layanan Khusus di Perguruan Tinggi, yang menyatakan bahwa unit layanan berkebutuhan khusus dapat dibentuk oleh perguruan tinggi sebagai pusat sumber untuk mendukung penyelenggaraan Pendidikan Khusus. ${ }^{91}$ Unit Layanan Disabilitas ini memiliki beberapa fungsi antara lain.

\footnotetext{
${ }^{89}$ Berdasarkan hasil wawancara dengan Phieter Angdika, selaku mahasiswa jurusan Sastra Indonesia, semester 3, Universitas Sanata Dharma, tertanggal 29 Agustus 2018.

90 Yang dimaksud dengan Pendidikan Khusus adalah layanan pendidikan bagi mahasiswa berkubutuhan khusus di perguruan tinggi, salah satunya yaitu orang Tuli. Lihat Pasal 1 angka 1, dan Pasal 3 ayat (2) Peraturan Menteri Riset, Teknologi, dan Pendidikan Tinggi Nomor 46 Tahun 2017 tentang Pendidikan Khusus dan Pendidikan Layanan Khusus di Perguruan Tinggi.

${ }^{91}$ Lihat juga Pasal 10 Peraturan Menteri Pendidikan dan Kebudayaan Nomor 46 Tahun 2014 tentang Pendidikan Khusus, Pendidikan Layanan Khusus dan/atau Pembelajaran Layanan Khusus pada Pendidikan Tinggi.
}

Cite this as:

Luhulima, Hendro Valence. Implementation Of Devotional Rights On Accessibility And Communication Based On Undang-Undang Nomor 8 Tahun 2016 Concerning Disabilities. Indonesian Journal of Disability Studies (IJDS).2018: Vol. 5(2): PP 268-295.
1) Meningkatkan kompetesi dosen maupun tenaga kependidikan dalam menangani mahasiswa berkebutuhan khusus;

2) Mengawasi dan mengevaluasi pelaksanaan penyesuaian yang layak bagi mahasiswa berkebutuhan khusus;

3) Menyediakan layanan konseling kepada mahasiswa berkebutuhan khusus; dan

4) Meningkatkan budaya inklusif di perguruan tinggi.

Kehadiran Unit Layanan Disabilitas seperti di Universitas Sanata Dharma akan sangat membantu orang Tuli dalam aktivitas perkuliahan. Selain itu, Unit Layanan Disabilitas dapat juga dijadikan sebagai sarana untuk pengembangan potensi diri orang Tuli, seperti kertelibatan dalam kajian-kajian khusus mengenai orang Tuli yang difasilitasi oleh Unit Layanan Disabilitas. Pada intinya, hadirnya unit layanan ini sebagai penghubung antara orang Tuli dengan pemangku kepentingan di perguruan tinggi untuk memperhatikan aksesibilitas orang Tuli di bidang pendidikan.

Berkaca pada kondisi kedua ini, berarti telah ada perguruan tinggi yang menerapkan pendidikan inklusif bagi orang Tuli. Kondisi ini yang idealnya diharapkan terjadi di Indonesia. ${ }^{92}$ Oleh karena itu sangat dibutuhkan kerja sama diantara Pemerintah dengan pemangku kepentingan untuk mewujudkan hal tersebut. Tidak menutup kemungkinan Lembaga Swadaya Masyarakat (LSM) yang peduli akan Penyandang Disabilitas atau organisasi Tuli juga turut bersama-sama membantu Pemerintah, karena selama ini Pemerintah Indonesia lewat Kementerian Pendidikan masih menemukan sejumlah tantangan untuk mewujudkan pendidikan inklusif. Kendala yang dimaksud seperti keterbatasan sekolah reguler yang mau menerapkan sekolah inklusif, masih ada penolakan dari orang tua anak Penyandang Disabilitas, bahkan program pendidikan di tingkat provinsi dan kabupaten/kota juga kurang mendukung pelaksanaan Sekolah

\footnotetext{
92 Berdasarkan Data Statistik Pendidikan, Kementerian Pendidikan selama tahun 2016 telah berhasil menambah jumlah sekolah inklusif hingga total mencapai 31.724 sekolah dengan jumlah siswa mencapai 159.001 anak. Lihat Tempo.co, "Sarana Pendidikan Inklusif Harus Diperluas", https://nasional.tempo.co/read/911696/saranapendidikan-inklusif-harus-diperluas/full\&view $=0 k$, diakses 7 Oktober 2018.
} 
Inklusif. ${ }^{93}$ Berkaitan dengan hal tersebut, peran serta LSM atau organisasi dari Penyandang Disabilitas - kalau untuk Tuli seperti Gerkatin - dapat menjadi perpaduan yang tepat untuk mengadvokasi terwujudnya pendidikan inklusif.

Contoh sederhana dari peran LSM untuk mengadvokasi hak-hak Penyandang Disabilitas seperti yang dilakukan oleh Sentra Advokasi Perempuan, Difabel, dan Anak (SAPDA) di kota Yogyakarta. Pemerintah Kota Yogyakarta mempunyai misi untuk mewujudkan Kota Yogyakarta sebagai Kota Inklusi. SAPDA hadir untuk memberikan pemahaman, penguatan, bahkan dorongan agar Pemerintah Kota Yogyakarta mempercepat perwujudan misi tersebut. Salah satu langkah yang dilakukan misalnya memberikan sosialisasi pemantapan kecamatan inklusi, dengan salah satu upaya yaitu menyediakan pendidikan inklusif, sebagai hak dasar dari Penyandang Disbilitas atas pendidikan. ${ }^{94}$

\section{b. Transportasi Umum}

Pemerintah dan Pemerintah Daerah wajib menyediakan pelayanan publik yang mudah diakses oleh orang Tuli. ${ }^{95}$ Pelayanan publik yang dimaksud ini termasuk pelayanan jasa transportasi publik. ${ }^{96}$ Sehubungan dengan transportasi publik, Menteri Perhubungan memberikan jaminan bagi orang Tuli untuk dapat mengakses dengan mudah pelayanan jasa transportasi lewat pembentukan Peraturan Menteri Perhubungan Nomor PM 98 Tahun 2017 tentang Penyediaan Aksesibilitas pada Pelayanan Jasa Transportasi Publik bagi Pengguna Jasa Berkebutuhan Khusus.

Peraturan ini mewajibkan penyelenggara jasa transportasi publik untuk melaksanakan pelayanan bagi penggua jasa berkebutuhan khusus. Untuk melaksanakan pelayanan tersebut, penyelenggara jasa layanan harus menyediakan sarana dan prasarana layanan yang aksesibel bagi pengguna jasa berkebutuhan khusus, termasuk orang Tuli.

\footnotetext{
93 Ibid.

94 Berdasarkan hasil wawancara dengan Ayatulloh Rohulloh Khomaini (Mico) selaku Program Manager pada Sentra Advokasi Perempuan, Difabel, dan Anak (SAPDA), tertanggal 19 September 2018.

${ }^{95}$ Lihat Pasal 105 ayat (1) UU No. 8 Tahun 2016 tentang Penyandang Disabilitas.

${ }^{96}$ Lihat Pasal 105 ayat (2) UU No. 8 Tahun 2016 tentang Penyandang Disabilitas.
}

Adapun sarana dan prasarana yang dimaksud ialah sebagai berikut.

Tabel 2. Aksesibilitas pada Sarana Transportasi ${ }^{97}$

Alat bantu untuk naik turun dari dan ke sarana transportasi

Pintu yang aman dan mudah diakses

Informasi audio/visual tentang perjalanan yang mudah di akses

Tanda/petunjuk khusus pada area pelayanan di sarana transportasi yang mudah di akses

Tempat duduk prioritas dan toilet yang mudah diakses

Penyediaan fasilitas bantu yang mudah diakses, aman, dan nyaman

Tabel 3. Aksesibilitas pada Prasarana Transportasi ${ }^{98}$ Ubin tekstur pemandu (guiding block) pada prasarana transportasi (pedestrian, loket, toilet)

Tanda/petunjuk khusus pada area pelayanan yang mudah di akses (parkir, loket, toilet)

Informasi visual/audio terkait informasi perjalanan

Pintu/gate aksesibel dengan dimensi yang sesuai dengan lebar kursi roda

Area menaikkan dan menurunkan penumpang (drop zone)

Ramp dengan kemiringan yang sesuai

Akses untuk naik turun penumpang yang aksesibel pada bangunan bertingkat

Toilet yang aksesibel dengan dimensi pintu toilet yang sesuai dengan lebar kursi roda

Loket tiket/counter khusus ticketing yang mudah diakses

Ruang tunggu dengan kursi prioritas

Ruang menyusui/nursery room dilengkapi dengan fasilitas sofa, baby tafel setinggi pinggang wanita, penyejuk udara, wastafel, tempat sampah, dan dispenser air minum

Poliklinik

Ruang bermain anak

Tempat parkir

Akses bahaya kebakaran

Ketersediaan kursi roda yang siap pakai

Berdasarkan hal tersebut di atas, paling tidak terdapat satu bentuk aksesibilitas yang

\footnotetext{
${ }^{97}$ Lihat Pasal 3 Peraturan Menteri Perhubungan Nomor PM 98 Tahun 2017 tentang Penyediaan Aksesibilitas pada Pelayanan Jasa Transportasi Publik bagi Pengguna Jasa Berkebutuhan Khusus.

${ }^{98}$ Lihat Pasal 4 Peraturan Menteri Perhubungan Nomor PM 98 Tahun 2017 tentang Penyediaan Aksesibilitas pada Pelayanan Jasa Transportasi Publik bagi Pengguna Jasa Berkebutuhan Khusus.
} 285

Cite this as:

Luhulima, Hendro Valence. Implementation Of Devotional Rights On Accessibility And Communication Based On Undang-Undang Nomor 8 Tahun 2016 Concerning Disabilities. Indonesian Journal of Disability Studies (IJDS).2018: Vol. 5(2): PP 268-295. 
DOI:

dapat memudahkan orang Tuli untuk menggunakan jasa transportasi, yaitu informasi visual mengenai informasi perjalanan. Berdasarkan pengamatan peneliti dan hasil wawancara dengan responden, untuk moda transportasi darat seperti Transjogja, informasi visual mengenai informasi perjalanan sudah sediakan. Kendati demikian, masih ditemukan pada beberapa sarana dan prasarana Transjogja, informasi visual yang ditampilkan pada monitor tidak berfungsi. Ada juga yang berfungsi tetapi tidak menampilkan informasi sesuai dengan kenyataannya. Hal ini sangat merugikan orang Tuli terutama pada halte-halte tertentu yang tidak mempunyai personil atau sumber daya yang ditempatkan dihalte tersebut. Apabila ada personil Transjogja yang ditugaskan di halte tertentu, permasalahan informasi visual pada halte tidak akan menjadi suatu kendala untuk orang Tuli, karena orang Tuli dapat bertanya secara langsung kepada personil yang bersangkutan.

Menurut Mico, permasalahan sebagaimana disebutkan di atas sebenarnya tidak perlu terjadi ketika ada pengawasan dari Pemerintah. Pasal 27 UU No. 8 Tahun 2016 tentang Penyandang Disabilitas telah secara tegas mengatakan bahwa Pemerintah, baik di tingkat pusat maupun daerah wajib melakukan evaluasi berkaitan dengan pelaksanaan penghormatan, perlindungan dan pemenuhan hak Penyandang Disabilitas. Sehubungan dengan itu, informasi visual yang disediakan tujuannya ialah untuk membantu orang Tuli mendapatkan haknya, berarti hal tersebut berkaitan dengan pemenuhan hak orang Tuli. Apabila dalam prakteknya pemenuhan hak orang Tuli tidak berjalan dengan lancar, Pemerintah sudah seharusnya segera mengevaluasinya, kendala yang dihadapi seperti apa, dan bagaimana solusinya. Ketentuan mengenai evaluasi ini diatur dengan Peraturan Pemerintah, namun sampai dengan saat ini Peraturan Pemerintah yang dimaksud belum terbentuk. ${ }^{99}$ Hal ini menjadi permasalahan tersendiri yang perlu diselesaikan oleh Pemerintah.

Permasalahan berikut ialah pengumuman atau informasi yang disampaikan oleh personil jasa transportasi masih mengandalkan bunyi/suara. Khusus di Transjogja hal ini dimungkinkan untuk disesuaikan dengan

\footnotetext{
99 Lihat Aria Indrawati dalam "Tujuh Peraturan Pemerintah Merangkak", Kompas, 1 Maret 2018.
}

kebutuhan orang Tuli ketika personil yang bersangkutan mengetahui ada penumpang Tuli. Penyesuaian dimaksud misalnya yang biasanya mengumumkan lokasi tujuan secara lisan, diganti dengan tulisan yang ditujukan khusus untuk orang Tuli. Namun hal ini tampaknya tidak berlaku ketika orang Tuli mengakses jasa transportasi udara, seperti pesawat, dan jasa transportasi darat, seperti kereta. ${ }^{100}$

Di stasiun kereta api maupun bandar udara, pengumuman lewat microphone sudah menjadi sesuatu hal yang lazim. Kebiasaan ini sering menjadi kendala bagi orang Tuli, terlebih lagi ketika ada informasi mengenai pergantian pesawat, pergantian pintu keberangkatan, perpindahan jalur, dan sebagainya. Pihak stasiun kereta api dan bandar udara tentu mengetahui hal ini dan mengantisipasinya dengan pemberian informasi visual yang ditayangkan lewat layar monitor. Kendati demikian, muncul permasalahan baru, yaitu sebagai berikut.

1) Layar monitor ini sering dialihfungsikan menjadi TV dan bukan untuk menampilkan informasi tujuan;

2) Monitor tersebut tidak berfungsi. Kalaupun berfungsi, informasi yang ditampilkan tidak sesuai;

3) Informasi visual hanya disediakan melalui satu atau dua monitor saja;

4) Penempatan monitor ini pun sangat jauh, ditambah ukurannya yang sangat kecil. Apabila orang Tuli ingin mengaksesnya harus bolak-balik dari tempat duduknya ke tempat monitor tersebut berada karena tempat duduk di dekat monitor itu sudah ditempati orang dengar. Hal ini dianggap tidak efisien. Sebaiknya informasi visual ini disediakan pada layar monitor yang besar, dan ditempatkan pada satu titik yang dapat dilihat oleh semua orang dengan mudah - meskipun dari jarak pandang yang jauh sekalipun. ${ }^{101}$ Apabila tidak bisa

\footnotetext{
${ }^{100}$ Peneliti hanya menyampaikan mengenai aksesibilitas pada transportasi darat seperti Transjogja, Kereta Api, dan transportasi udara seperti pesawat karena ketiga transportasi tersebut yang sering digunakan oleh orang Tuli untuk melakukan perjalanan ke tempat-tempat tertentu. Orang Tuli yang dimaksud ialah orang Tuli yang menjadi responden penelitian ini.

101 Berdasarkan hasil wawancara dengan Ayatulloh Rohulloh Khomaini (Mico) selaku Program Manager pada
} 286 
menyediakan seperti itu, tidak menjadi masalah apabila layar monitornya kecil, tetapi jumlahya diperbanyak. Kemudian, tempat duduk di dekat monitor tersebut dapat diberikan tanda khusus yang diprioritaskan bagi orang Tuli atau Penyandang Disabilitas yang lain.

Permasalahan di atas juga dapat diatasi ketika ada pendampingan khusus kepada orang Tuli. Sebenarnya Peraturan Menteri Perhubungan Nomor PM 98 Tahun 2017 tentang Penyediaan Aksesibilitas pada Pelayanan Jasa Transportasi Publik bagi Pengguna Jasa Berkebutuhan Khusus, sudah memberikan jalan keluar untuk itu. Jalan keluarnya adalah menyediakan ruang pusat informasi, dan personel yang dapat membantu Penyandang Disabilitas. Kedua hal tersebut wajib disediakan oleh penyelenggara sarana dan prasarana transportasi. ${ }^{102}$ Personil yang disediakan ini akan dibekali dengan pelatihan terkait pelayanan bagi Penyandang Disabilitas baik sarana maupun di prasarana transportasi. Jadi, apabila bertemu dengan orang Tuli, personel ini sudah mengetahui cara-cara yang benar dan tepat untuk berkomunikasi atau memenuhi kebutuhan orang Tuli.

Di bidang penerbangan, Pasal 239 ayat (2) huruf e Undang-Undang Nomor 1 Tahun 2009 tentang Penerbangan mengamanatkan bahwa Penyandang Disabilitas berhak memperoleh pelayanan berupa perlakuan dan fasilitas khusus seperti tersedianya personel yang khusus bertugas untuk melayani atau berkomunikasi dengan Penyandang Disabilitas. Namun tampaknya hal ini belum diimplementasikan, sebab para responden yang berpergian menggunakan pesawat, khususnya melalui Bandar Udara Internasional Adi Sutjipto, tidak pernah menerima perlakuan dan fasilitas khusus seperti ini. Hal yang sama juga berlaku ketika berpergian menggunakan kereta api, tidak ada fasilitas khusus yang diberikan kepada orang Tuli. Padahal di dalam Pasal 131 ayat (1) Undang-Undang Nomor 23 Tahun 2007 tentang Perkeretaapian mewajibkan penyelenggara sarana perkeretaapian untuk memberikan

Sentra Advokasi Perempuan, Difabel, dan Anak (SAPDA), tertanggal 19 September 2018.

102 Lihat Pasal 5 Peraturan Menteri Perhubungan Nomor PM 98 Tahun 2017 tentang Penyediaan Aksesibilitas pada Pelayanan Jasa Transportasi Publik bagi Pengguna Jasa Berkebutuhan Khusus. fasilitas khusus dan kemudahan bagi Penyandang Disabilitas. ${ }^{103}$

\section{c. Partisipasi dalam Rekreasi}

Sebelum menjelaskan lebih lanjut mengenai aksesibilitas dalam bidang rekreasi, perlu dijelaskan terlebih dahulu pengertian rekreasi yang dimaksud pada bagian ini. Istilah rekreasi berasal dari bahasa latin yaitu "recreation" yang berarti pemulihan kesehatan. ${ }^{104}$ Atau dengan kata lain istilah ini memiliki makna sebagai proses yang memulihkan kembali kesehatan seseorang. Daniel McLean dan Amy Hurd dalam bukunya yang berjudul Kraus' Recreation and Leisure in Modern Society mendefinisikan rekreasi sebagai berikut.

Recreation, from an individual perspective, involves, as an example, watching television, attending an opera, base jumping, mowing the lawn, taking your children to the zoo, playing checkers, downloading music, writing a book, an evening on the town, or whatever one chooce to make it. ${ }^{105}$

Selain itu, berdasarkan Dictionary of Sociology, rekreasi diartikan sebagai kegiatan apapun yang dilakukan selama waktu senggang, baik secara individu maupun kolektif, yang bebas dan menyenangkan, serta memiliki daya tarik tersendiri. ${ }^{106}$ Sejalan dengan itu, Sport Recreation and Amenities dalam Endang Sepdianus dan FX Sugiyanto, menegaskan bahwa rekreasi mengacu pada kegiatan yang sifatnya informal, tidak terstruktur, kegiatan pada waktu luang yang memungkinkan untuk adanya partisipasi massa namun dapat juga dilakukan secara individu. ${ }^{107}$

\footnotetext{
${ }^{103}$ Mengenai hal tersebut perlu diteliti lebh lanjut apakah pihak bandar udara atau stasiun kereta sudah menjalankan kewajibannya untuk membantu dan memberikan kemudahan bagi orang Tuli dalam mengakses layanan jasa yang disediakan oleh pihak bandar udara maupun stasiun kereta.

${ }^{104}$ Liis Meeras, 2010, Leisure and Recreation, Parnu: University of Tartu, hlm. 12.

105 Daniel McLeanand, dan Amy Hurd, 2015, Kraus' Recreation and Leisure in Modern Society, Burlington: Jones \& Bartlett Learning, hlm. 1-2.

${ }^{106}$ Ibid.

${ }^{107}$ Endang Sepdianus dan FX Sugiyanto, "Model Aktivitas Rekreatif Kompetitif untuk Meningkatkan Kesehatan Psikososial dan Memelihara Daya Ingat Lansia", Medikora, Volume 14, Nomor 2, 2015, hlm. 3.
}

Cite this as: 287

Luhulima, Hendro Valence. Implementation Of Devotional Rights On Accessibility And Communication Based On Undang-Undang Nomor 8 Tahun 2016 Concerning Disabilities. Indonesian Journal of Disability Studies (IJDS).2018: Vol. 5(2): PP 268-295. 
Berdasarkan penjelasan di atas, dapat disimpulkan bahwa yang dimaksud dengan rekreasi ialah kegiatan yang dilakukan pada waktu luang, baik secara individu maupun kelompok dengan tujuan untuk memulihkan keadaan diri seseorang. ${ }^{108}$ Adapun bentuk kegiatan yang tergolong pada rekreasi ini, misalnya yang digambarkan oleh Baud-Bovy dan Lawson sebagaimana dikutip oleh Liis Meeras berikut ini.

Tabel 4. Kategori Kegiatan Rekreasi ${ }^{109}$

\begin{tabular}{|l|l|}
\hline \multicolumn{1}{|c|}{ Kategori Kegiatan } & \multicolumn{1}{|c|}{ Contoh } \\
\hline Kegiatan di rumah & $\begin{array}{l}\text { Menonton } \\
\text { membaca, mendengarkan } \\
\text { musik, berkebun, dan } \\
\text { bermain komputer. }\end{array}$ \\
\hline Kegiatan sosial & $\begin{array}{l}\text { Berpesta mengunjungi } \\
\text { teman dan kerabat, } \\
\text { minum di bar. }\end{array}$ \\
\hline $\begin{array}{l}\text { Kebudayaan, dan } \\
\text { pendidikan, } \\
\text { karya seni }\end{array}$ & $\begin{array}{l}\text { Pergi ke bioskop, konser, } \\
\text { pameran, museum. }\end{array}$ \\
\hline Olahraga & $\begin{array}{l}\text { Golf, sepak bola, } \\
\text { berenang, bermain tenis. }\end{array}$ \\
\hline $\begin{array}{l}\text { Rekreasi informal di } \\
\text { luar rumah }\end{array}$ & $\begin{array}{l}\text { Jalan santai, piknik, } \\
\text { berkeliling } \\
\text { kendaraan. }\end{array}$ \\
\hline
\end{tabular}

Berdasarkan hal tersebut di atas, ada dua jenis kegiatan rekreasi yang menjadi sorotan peneliti berkaitan dengan hak orang Tuli atas aksesibilitas yaitu akses terhadap program TV, dan akses terhadap tempat pertunjukan seperti bioskop. Hal sebagaimana disebutkan ini lalai untuk memperhitungkan kebutuhan informasi orang Tuli. Orang Tuli tidak diberikan kesempatan yang sama untuk mengambil manfaat dalam penyampaian informasi maupun hiburan yang disajikan. Alasannya karena banyak sekali informasi yang disampaikan

\footnotetext{
108 Rekreasi mempunyai pengertian yang beraneka ragam, tergantung dari persepsi individu. Akibatnya, hal ini juga menghasilkan berbagai kegiatan yang berbedabeda untuk mengkategorikan mana yang termasuk rekreasi dan mana yang bukan. Terkadang istilah ini diterapkan untuk membedakan kegiatan anak muda, orang dewasa, dan anak kecil. Dikarenakan keragaman dalam penggunaan kata ini, perlu diperjelas bahwa rekreasi memiliki makna yang lebih komprehensif dan tidak terbatas pada kelompok usia dan aktivitas tertentu. Lihat Aafid Gulam, "Recreation - Need and Importance in Modern Society", International Journal of Physiologi, Nutrition and Physical Education, Volume 1, Nomor 2, 2016, hlm. 157.

${ }^{109}$ Liis Meeras, Op. Cit., hlm. 4.
}

secara lisan dan mengharuskan penonton untuk mendengar, sedangkan orang Tuli tidak bisa melakukan hal tersebut. Oleh karena itu, kebutuhan akan caption selalu diperjuangkan orang Tuli untuk dapat digunakan di televisi maupun film-film yang ditayangkan pada bioskop, khususnya film-film Indonesia. ${ }^{110}$

Caption adalah teks yang muncul di layar yang berfungsi menjelaskan isi video dan juga untuk menggantikan peran suara dalam menyampaikan pesan. Caption memiliki tiga bentuk, yaitu open captions (OC), closed captions (CC), dan real-time captions (RTC). OC merupakan keterangan atau teks yang selalu terintegrasi dan melekat pada video setiap waktu. Apabila teks tersebut dapat di nonaktifkan oleh pengguna, maka teks tersebut adalah CC. Dengan kata lain yang dimaksud dengan CC adalah teks yang perlu diaktifkan terlebih dahulu melalui pengaturan alat sebelum digunakan. ${ }^{111}$ Kemudian, RTC adalah keterangan yang sering digunakan untuk live show, misalnya untuk kegiatan ceramah, dan pertunjukan teater. ${ }^{112}$

Selama ini para responden tidak pernah menonton film Indonesia yang ditayangkan pada bioskop, maupun jarang sekali menonton televisi. Alasannya sederhana yaitu televisi dan film-film Indonesia yang ditayangkan dibioskop tidak memiliki caption text - dan Juru Bahasa Isyarat khususnya pada program berita di televisi. Tanpa caption text orang Tuli tidak akan mengerti apa yang disampaikan oleh para pemain. Sangat tidak dimungkinkan apabila orang Tuli diharuskan untuk membaca gerak bibir para pemain dari awal sampai berakhirnya film tersebut. Tujuan orang Tuli datang ke bioskop untuk menghibur diri, dan bersenang-senang, namun dengan kondisi tidak ada caption text dan mengharuskan untuk membaca gerak bibir justru akan membuat orang Tuli menjadi lelah dan stress.

Selama ini Pemerintah mengharapkan untuk warga negaranya mencintai produk Indonesia, dan bangga akan karya Indonesia, termasuk film. Namun bagaimana bisa orang

\footnotetext{
${ }^{110}$ Berdasarkan hasil wawancara dengan Phieter Angdika, tertanggal 29 Agustus 2018.

${ }^{111}$ Contoh dari closed captions dapat dilihat pada layanan YouTube. Cara mengaktifkannya yaitu dengan memilih tulisan "CC" yang berada di kanan bawah video.

${ }^{112}$ Kristina Johnson, 2013, Accessibility for Deaf and Hard of Hearing Audiences at Cultural Institutions, A Project Access White Paper, Art Beyond Sight, hlm. 5.
} 288 
Tuli melakukan atau merasakan hal yang sama sedangkan orang Tuli tidak diberikan akses untuk menikmati film-film yang dihasilkan. Gerkatin sebagai organisasi yang memperjuangkan hak-hak orang Tuli terus mendorong Pemerintah untuk menyediakan caption text, terkhusus closed captions di televisi. ${ }^{113}$

Adapun alasan caption text lebih di dorong penggunaannya daripada Juru Bahasa Isyarat ialah karena pertimbangan efektifitas dan efisiensi. ${ }^{114}$ Seorang juru Bahasa Isyarat akan sulit melakukan tugasnya apabila ia harus menjurubahasakan semua bahasa lisan dan kondisi yang ada pada layanan televisi, terutama iklan ke dalam Bahasa Isyarat. ${ }^{115}$ Apabila informasi yang disampaikan seperti berita, seorang juru Bahasa Isyarat akan sangat memungkinkan untuk melakukan tugasnya seperti praktek yang selama ini berlangsung pada beberapa televisi nasional/swasta. Alasan berikutnya ialah tidak semua orang Tuli mengerti akan Bahasa Isyarat yang ditampilkan, sehingga hal ini dirasakan kurang efektif. Oleh sebab itu, caption text dianggap sebagai jalan keluar yang tepat untuk mengisi celah diantara orang Tuli yang tidak mengerti dan yang mengerti Bahasa Isyarat. ${ }^{116}$

Selain alasan yang disebutkan di atas, ada juga pertimbangan lain yang menguatkan

\footnotetext{
113 Gerkatin Dewan Pengurus Cabang DIY pernah mengadakan lokakarya mengenai aksesibilitas layanan publik untuk Tuli pada tanggal 13 Juli 2018 bertempat di Hotel Arjuna Yogyakarta. Lokakarya ini diadakan sebagai tindak lanjut dari Focus Group Discussion yang pernah dilakukan oleh organisasi Tuli dan perwakilan Pemerintah pada bulan Februari 2018. Lokakarya ini diselenggarakan dengan tujuan untuk memaparkan solusi atas permasalahan-permasalahan yang muncul berkaitan dengan hak-hak orang Tuli. Salah satu permasalahan yang dikemukakan ialah masih banyak saluran dan acara televisi yang tidak memberikan akses teks Bahasa Indonesia dan kolom juru Bahasa Isyarat. Ramadhany Rahmi, "Gerkatin DIY Upayakan Aksesibilitas Layanan Publik untuk Tuli", https://www.solider.id/baca/4657gerkatin-diy-upayakan-aksesibilitas-layanan-publik-tuli, diakses pada 27 September 2018.

${ }^{114}$ Kendati demikian, bukan berarti Juru Bahasa Isyarat tidak diperlukan lagi. Penggunaan Bahasa Isyarat lewat seorang Juru Bahasa Isyarat pada setiap televisi tetap didorong untuk terus dilakukan sebagai bentuk memperkenalkan Bahasa Isyarat secara meluas.

${ }^{115}$ Berdasarkan hasil wawancara dengan Phieter Angdika, tertanggal 29 Agustus 2018.

${ }^{116}$ Alasan-alasan ini juga berlaku bagi perlunya caption text pada film-film yang diputarkan di bioskop.
}

Cite this as: pernyataan mengapa caption text itu diperlukan. Pertimbangan tersebut adalah bahwa Bahasa Isyarat dalam penyiaran televisi hanya digunakan dalam mata acara tertentu, seperti berita ${ }^{117}$, sedangkan untuk program-program lainnya tidak diwajibkan untuk menggunakan Bahasa Isyarat. Hal ini sesuai dengan redaksi dari Pasal 39 ayat (3) Undang-Undang Nomor 32 Tahun 2002 tentang Penyiaran sebagai berikut "Bahasa isyarat dapat digunakan dalam mata acara tertentu untuk khalayak tunarungu". Kata "dapat" dan "mata acara tertentu" merupakan kelemahan dan pembatasan bagi orang Tuli untuk mengakses secara penuh haknya atas hiburan atau informasi yang disampaikan lewat televisi. Ketentuan pada Pasal 39 ayat (3) ini secara tidak langsung mengindikasikan bahwa penggunaan Bahasa Isyarat dalam program televisi akan dikembalikan pada kebijakan masing-masig lembaga penyiaran karena tidak ada suatu keharusan di dalam ketentuan tersebut. Dengan demikian, untuk memberikan kesempatan yang sama dan seluas-luasnya bagi orang Tuli untuk mengakses informasi dan hiburan baik itu di televisi, maupun bioskop sebaiknya menggunakan caption text dengan alasan-alasan yang telah dijelaskan sebelumnya.

Melihat kondisi yang terjadi saat ini, tentu sangat bertolak belakang dengan apa yang seharusnya terjadi dan diamanatkan oleh CRPD. Pada Pasal 30 ayat (1) CRPD menegaskan bahwa negara pihak konvensi Indonesia juga termasuk di dalamnya mengakui hak-hak Penyandang Disabilitas untuk berperan atas dasar kesamaan dengan orang lain dalam kehidupan kebudayaan, dan akan mengambil langkah-langkah yang diperlukan untuk memastikan agar Penyandang Disabilitas:

1) Menikmati akses terhadap benda-benda kebudayaan;

2) Menikmati akses terhadap program televisi, film, teater, dan kegiatan

\footnotetext{
${ }^{117} \mathrm{Hal}$ ini disimpulkan berdasarkan praktek yang terjadi di lapangan selama ini, dan didukung dengan Siaran Pers No. 232/HM/KOMINFO/09/2018 dari Kementerian Komunikasi dan Informatika pada peringatan Hari Bahasa Isyarat Internasional tertanggal 23 September 2018, yang mewajibkan televisi siaran untuk menyediakan tayangan Bahasa Isyarat Indonesia dalam program berita.
}

Luhulima, Hendro Valence. Implementation Of Devotional Rights On Accessibility And Communication Based On Undang-Undang Nomor 8 Tahun 2016 Concerning Disabilities. Indonesian Journal of Disability Studies (IJDS).2018: Vol. 5(2): PP 268-295. 
kebudayaan lain dalam bentuk yang mudah diakses;

3) Menikmati akses ke tempat-tempat pertunjukan atau pelayanan budaya, seperti bioskop, museum, teater, perpustakaan, dan jasa pariwisata, dan sejauh memungkinkan, menikmati akses ke monumen dan tempat yang memiliki nilai budaya penting.

Berdasarkan ketentuan tersebut, terlihat jelas bahwa aksesibilitas atas program televisi, film, dan bioskop juga menjadi salah satu prioritas bagi orang Tuli, bahkan hal tersebut telah diakui oleh negara peserta konvensi termasuk Indonesia. Indonesia telah meratifikasi CRPD dengan Undang-Undang Nomor 19 Tahun 2011 tentag Pengesahan Convention on the Rights of Persons with Disabilities (Konvensi mengenai Hak-Hak Penyandang Disabilitas). Dengan demikian Indonesia berkewajiban untuk memenuhi amanat dari Pasal 30 tersebut, apalagi ketentuan Pasal ini juga tidak direservasi oleh Indonesia. ${ }^{118}$

Temuan peneliti juga sama dengan Laporan Bayangan Indonesia mengenai Implementasi CRPD, secara khusus Pasal 30, yang disampaikan oleh Tim Konvensi Disabilitas Indonesia. Tim tersebut menyampaikan bahwa Indonesia belum melakukan upaya dan penyediaan akomodasi yang layak, alat, serta sarana prasarana yang menjamin orang Tuli menikmati situs-situs bernilai budaya, termasuk aksesibilitas di bioskop, rumah pertunjukan dan lokasi wisata. ${ }^{119}$ Selain itu, jaminan memperoleh informasi atau hiburan dalam format yang dapat diakses oleh orang Tuli seperti captioning juga belum tersedia. ${ }^{120}$ Padahal di dalam Laporan Pertama Pelaksanaan CRPD oleh Pemerintah Indonesia dinyatakan bahwa Kementerian Sosial dan Kementerian Pendidikan dan Kebudayaan sedang mengembangkan $\mathrm{MoU}$

\footnotetext{
118 United Nations, "Status of Treaties: Chapter IV Human Rights, Convention on the Rights of Persons with Disabilities",

https://treaties.un.org/doc/Publication/MTDSG/Volume\% 20I/Chapter\%20IV/IV-15.en.pdf, diakses pada 27 September 2018.

119 Lihat Laporan Bayangan Indonesia mengenai Implementasi Konvensi PBB Hak-Hak Penyandang Disabilitas, Maret 2017, angka 202.

${ }^{120}$ Lihat Ibid., angka 143.
}

dengan perusahaan televisi swasta untuk menyediakan akses informasi bagi orang Tuli. ${ }^{121}$ Ditambah lagi Komisi Penyiaran Indonesia juga sudah memiliki kebijakan mengenai bahasa siaran yang bisa diakses oleh semua Penyandang Disabilitas, termasuk orang Tuli, namun hal tersebut belum terlaksana secara maksimal. ${ }^{122}$ Kendati demikian, kesadaran Pemerintah akan hak orang Tuli ini sudah terlihat, hanya saja tinggal didorong agar kesadaran ini mau diaktualisasikan lewat program yang nyata. ${ }^{123}$

Di dalam UU No. 8 Tahun 2016 tentang Penyandang Disabilitas, tidak secara eksplisit mengatur mengenai partisipasi Penyandang Disabilitas dalam rekreasi, dan hiburan. Namun apabila ditelusuri lebih lanjut, Pasal 18 mengenai hak aksesibilitas dapat digunakan sebagai dasar untuk orang Tuli menuntut haknya atas aksesibilitas program televisi, film, dan bioskop. Pasal 18 tersebut berisikan ketentuan bahwa hak aksesibilitas Penyandang Disabilitas meliputi mendapatkan akses untuk memanfaatkan fasilitas publik dan akomodasi yang layak sebagai bentuk aksesibilitas bagi individu. "Akomodasi yang layak" ini sangat diperlukan bagi orang Tuli untuk dapat menikmati film dan berbagai layanan informasi yang disajikan di televisi. Alasannya karena

\footnotetext{
${ }^{121}$ Lihat First Report of the Republic of Indonesia on the Implementation of the United Nations Convention on the Rights of Persons with Disabilities, 20 Desember 2016, angka 92. Dalam rangka memberikan akses informasi kepada orang Tuli, Pemerintah Indonesia juga sudah membuat Peraturan Pemerintah Nomor 50 Tahun 2005 tentang Penyelenggaraan Penyiaran Lembaga Penyiaran Swasta, yang mengatur penggunaan Bahasa Isyarat di televisi khusus Lembaga Penyiaran Swasta (Pasal 16 ayat (6)). Namun sayangnya Pasal tersebut mempunyai kelemahan yang sama dengan ketentuan Pasal 39 ayat (3) UU No. 32 Tahun 2002 tentang Penyiaran. Kedua Pasal tersebut tidak memberikan kewajiban bagi Lembaga Penyiaran untuk menggunakan Bahasa Isyarat, melainkan lebih diserahkan kepada kebijakan Lembaga Penyiaran itu sendiri - karena ada kata "dapat" pada Pasal tersebut. Hal ini juga termasuk menentukan mata acara tertentu yang dapat menggunakan Bahasa Isyarat, tanpa memberikan penjelasan lebih lanjut maksud "mata acara tertentu" pada Pasal tersebut itu seperti apa.

${ }_{122}$ Lihat Laporan Bayangan Indonesia mengenai Implementasi Konvensi PBB Hak-Hak Penyandang Disabilitas, Maret 2017, angka 142.

${ }^{123}$ Lihat Ali Akhmad Noor Hidayat, "Penggunaan Bahasa Isyarat di Televisi akan Diwajibkan", https://bisnis.tempo.co/read/1035259/penggunaanbahasa-isyarat-di-acara-televisi-akandiwajibkan/full\&view=ok, diakses 10 Oktober 2018.
} 290 
akomodasi yang layak mengharuskan adanya modifikasi dan penyesuaian yang tepat dan diperlukan untuk menjamin Penyandang Disabilitas menikmati atau melaksanakan semua HAM dan kebebasan fundamental berdasarkan kesetaraan. Semua hal ini diberikan sebagai wujud penghormatan dan pengakuan bahwa setiap orang dilahirkan di dunia ini mempunyai martabat dan hak yang sama ${ }^{124}$, sehingga tidak boleh ada pengurangan atau pengecualian hak asasi yang dimiliki oleh seseorang.

Rekreasi dan hiburan bukan merupakan sesuatu hal yang dapat disepelekan, melainkan memiliki kontribusi yang sangat penting bagi diri seseorang. Aafid Gulam mengemukakan beberapa alasan mengenai pentingnya hal tersebut antara lain.

1) Rekreasi merupakan kebutuhan fundamental setiap manusia. Rekreasi memungkinkan seseorang untuk lebih berani mengekspresikan dan mengembangkan dirinya;

2) Rekreasi sebagai sarana untuk menyeimbangkan kehidupan seseorang, terutama kehidupan di pekerjaan. Dengan rekreasi, seseorang dapat menjadi rileks ketika selesai atau sudah jenuh dengan pekerjaan yang menghabiskan tenaga dan pikiran. Rekreasi akan berfungsi untuk menjaga dan membuat seseorang bahagia;

3) Rekreasi telah diyakini sebagai penyumbang pembentukan karakter pribadi dan budaya nasional. Dengan rekreasi, seseorang akan diajarkan untuk menghormati aturan, memiliki keberanian, dan kemampuan meredam keegoisan individu untuk kepentingan bersama. Rekreasi tidak hanya mengembangkan kualitas individu tetapi sangat mempengaruhi pertumbuhan sikap sosial yang mempengaruhi individu sebagai anggota kelompok masyarakat;

4) Partisipasi dalam rekreasi yang sehat membantu membangun karakter seseorang, yang pada akhirnya akan berfungsi untuk mencegah tindakan kejahatan dan kenakalan. ${ }^{125}$

\footnotetext{
${ }^{124}$ Lihat Pasal 1 UDHR.

${ }^{125}$ Aafid Gulam, Op. Cit., hlm. 159.
}

Mengingat betapa pentingnya rekreasi dan hiburan bagi pengembangan diri individu, maka diperlukan akses bagi orang Tuli untuk berpartisipasi penuh di dalamnya. Tanpa adanya akses untuk berpartisipasi, seseorang tidak dapat menjelajahi lebih jauh mengenai potensi sosial, intelektual, emosional, komunikatif, dan fisiknya. Bahkan oleh Gillian King dikatakan sebagai berikut "Without adequate opportunities to participate (of recreation and leisure), people are [...] less able to grow as individuals. $^{126}$

\section{Kesimpulan}

Berdasarkan hasil penelitian dan pembahasan yang telah dikemukakan sebelumnya, dapat disimpulkan bahwa hak orang Tuli atas aksesibilitas dan komunikasi belum sepenuhnya diimplementasikan sesuai amanat UU No. 8 Tahun 2016 tentang Penyandang Disabilitas. Kendati demikian, bukan berarti hak-hak orang Tuli tersebut tidak dipenuhi sama sekali, melainkan dalam tahap perkembangan. Hal ini di karenakan terdapat dua kondisi yang peneliti temukan diantara orang-orang Tuli, yaitu orang Tuli yang telah terpenuhi haknya, dan orang Tuli yang belum terpenuhi haknya. Hal ini terlihat jelas pada hak atas komunikasi berupa Bahasa Isyarat, di mana orang Tuli dipaksakan untuk menggunakan bahasa lisan dan lip reading, padahal orang Tuli tersebut mempunyai Bahasa Isyarat sebagai bahasa komunikasi. Bagi orang Tuli hal ini sangat sulit untuk dilakukan, secara khusus bagi orang Tuli yang kesehariannya terlibat di dalam komunitas Tuli. Kondisi ini berbeda dengan orang Tuli yang selama ini berada pada lingkungan dan budaya orang dengar. Orang Tuli tersebut dapat dikatakan lebih sedikit memahami pesan yang disampaikan orang dengar ketika berkomunikasi menggunakan bahasa lisan dan lip reading, karena sejak kecil sudah dididik dengan budaya orang dengar dan bukan budaya orang Tuli. Kemudian mengenai hak atas aksesibilitas, kondisi yang ditemukan pun hampir sama dengan implementasi hak atas komunikasi. Salah satu contohnya yaitu akses penuh bagi orang Tuli untuk berpartisipasi dalam bidang rekreasi. Orang Tuli masih

\footnotetext{
${ }^{126}$ Gillian King, et al., "A Conceptual Model of the Factors Affecting the Recreation and Leisure Participation of Children with Disabilities", Physical \& occupational 291 
kesulitan dan terhambat untuk berpartisipasi penuh dalam bidang rekreasi, seperti mengakses program televisi, dan bioskop. Hal ini disebabkan informasi yang disampaikan lebih banyak mengandalkan bahasa lisan atau audio daripada mensulibahasakan informasi lisan ke dalam tulisan.

\section{Daftar Pustaka}

Cangara, H. Hafied, (2015), Pengantar Ilmu Komunikasi, Rajawali Press, Jakarta.

Chapman, Bernadette, (2008), Deafness and Mental Health: Guidelines for Working with People who are Deaf or Hard of Hearing, Queensland Health, Queensland.

McLeanand, Daniel dan Amy Hurd, (2015), Kraus' Recreation and Leisure in Modern Society, Jones \& Bartlett Learning, Burlington.

Muhammad, Abdulkadir, (2004), Hukum dan Penelitian Hukum, PT Citra Aditya Bakti, Bandung.

Mulyana, Deddy, (2008), Ilmu Komunikasi Suatu Pengantar, Remaja Rosdakarya, Bandung.

Sastropoetro, Santoso, (1991), Propaganda Salah Satu Bentuk Komunikasi Massa, Alumni, Bandung.

Sugiyono, (2014), Memahami Penelitian Kualitatif, Alfabeta, Bandung.

Suryanto, (2015), Pengantar Ilmu Komunikasi, Pustaka Setia, Bandung.

Yusup, Pawit M, (2009), Ilmu Informasi, Komunikasi, dan Kepustakaan, Bumi Aksara, Jakarta.

Undang-Undang Dasar Negara Republik Indonesia Tahun 1945.

Undang-Undang Nomor 4 Tahun 1997 tentang Penyandang Cacat (Lembaran Negara Republik Indonesia Tahun 1997 Nomor 9, Tambahan Lembaran Negara Republik Indonesia Nomor 3670).
Undang-Undang Nomor 32 Tahun 2002 tentang Penyiaran (Lembaran Negara Republik Indonesia Tahun 2002 Nomor 139, Tambahan Lembaran Negara Republik Indonesia Nomor 4252).

Undang-Undang Nomor 1 Tahun 2009 tentang Penerbangan (Lembaran Negara Republik Indonesia Tahun 2009 Nomor 1, Tambahan Lembaran Negara Republik Indonesia Nomor 4956).

Undang-Undang Nomor 19 Tahun 2011 tentang Pengesahan Convention on the Rights of Persons with Disabilities (Konvensi mengenai Hak-Hak Penyandang Disabilitas) (Lembaran Negara Republik Indonesia Tahun 2011 Nomor 107, Tambahan Lembaran Negara Republik Indonesia Nomor 5251).

Undang-Undang Nomor 8 Tahun 2016 tentang Penyandang Disabilitas (Lembaran Negara Republik Indonesia Tahun 2016 Nomor 69, Tambahan Lembaran Negara Republik Indonesia Nomor 5871).

Peraturan Pemerintah Nomor 50 Tahun 2005 tentang Penyelenggaraan Penyiaran Lembaga Penyiaran Swasta (Lembaran Negara Republik Indonesia Tahun 2005 Nomor 127, Tambahan Lembaran Negara Republik Indonesia Nomor 4566).

Peraturan Menteri Pendidikan dan Kebudayaan Nomor 46 Tahun 2014 tentang Pendidikan Khusus, Pendidikan Layanan Khusus dan/atau Pembelajaran Layanan Khusus pada Pendidikan Tinggi Berita Negara Republik Indonesia Tahun 2014 Nomor 787)

Peraturan Menteri Pekerjaan Umum Nomor 30/PRT/M/2006 tentang Pedoman Teknis Fasilitas dan Aksesibilitas pada Bangunan Gedung dan Lingkungan.

Peraturan Menteri Riset, Teknologi, dan Pendidikan Tinggi Nomor 46 Tahun 2017 tentang Pendidikan Khusus dan Pendidikan Layanan Khusus di Perguruan Tinggi (Berita Negara Republik Indonesia Tahun 2017 Nomor 926).

Peraturan Menteri Perhubungan Nomor PM 98 Tahun 2017 tentang Penyediaan Aksesibilitas

Luhulima, Hendro Valence. Implementation Of Devotional Rights On Accessibility And Communication Based On Undang-Undang Nomor 8 Tahun 2016 Concerning Disabilities. Indonesian Journal of Disability Studies (IJDS).2018: Vol. 5(2): PP 268-295. 
pada Pelayanan Jasa Transportasi Publik bagi Pengguna Jasa Berkebutuhan Khusus (Berita Negara Republik Indonesia Tahun 2017 Nomor 1385).

Universal Declaration of Human Rights 1948. International Covenant on Civil and Political Rights International Covenant on Economic, Social and Cultural Rights United Nations Convention on the Rights of Persons with Disabilities.General Comment No. 5: Persons with Disabilities, 9 December 1994, E/1995/22.

Abazari, Zahra dan Mahshid Borjian Brojeni, (2017) "The Role of Harold Laswell Communication Theory in Librarianship and Information Science", International Academics Journal of Humanities, Volume 4, Nomor 2

Brice, Patrick J dan Gillie, (2016), "Deaf Adolescents in a Hearing World: A Review of Factors Affecting Physchosocial Adaption", Adolescent Health, Medicine and Therapeutics, Volum 7, April 2016.

Dolnick, Edwardk, (1993) "Deafness as culture", The Atlantic, Volume 272, Nomor 3

Goss, Blaine, (2003), "Hearing for the Deaf Culture", Intercultural Communication Studies, Volume 12, Nomor 2

Gudykunst, William B. dan Tsukasa Nishida, (2000), "The Influence of Culture and Strength of Cultural Identity on Individual Values in Japan and the United States", Intercultural Communication Studies, Volume 9, Nomor 1

Gulam, Aafid, (2016), "Recreation - Need and Importance in Modern Society", International Journal of Physiologi, Nutrition and Physical Education, Volume 1, Nomor 2

Hiddinga, Anja dan Onno Crasborn, (2011), "Signed Languages and Globalization", Language Society, Volume 40, Nomor 4

Ilma, Naufal, (2015), "Peran Pendidikan sebagai Modal Utama Membangun Karakter Bangsa", Tadbir Jurnal Manajemen Pendidikan Islam, Volume 3, Nomor 1, Februari 2015.

King, Gillian, et al., (2003), "A Conceptual Model of the Factors Affecting the Recreation and Leisure Participation of Children with
Disabilities", Physical \& occupational therapy in pediatrics, Volume 23, Nomor 1, 2003.

Kurnia, Damaiati R, Thohari Slamet, (2016), "Menormalkan yang Dianggap Tidak Normal (Studi Kasus Penerbitan Bahasa Isyarat Tunarungu di Sekolah Luar Biasa (SLB) dan Perlawanannya di Kota Malang", Indonesian Journal of Disability Studies, Volume 3, Nomor 1

Marshall, Hermine H, (2001), "Cultural Influences on the Development of SelfConcept: Updating our thinking”, Young Children, Volume 56, Nomor 5

McNelly, Carla A, (2015), "Language Learning Policy through the Lens of Language as a Problem, as a Right, and as a Resources", NABE Journal of Research and Practice, Volume 6, Nomor 1

Mellon, Nancy K, et al., (2015), "Should All Deaf Children Learn Sign Language?", Pediatrics, Volume 135, Nomor 1

Muhardi, (2004), "Kontribusi Pendidikan dalam Meningkatkan Kualitas Bangsa Indonesia", Mimbar: Jurnal Sosial dan Pembangunan, Volume 20, Nomor 4, OktoberDesember 2004.

Nikolaraizi, Magda dan Kika Hadjikakou, (2006), "The Role of Educational Experience in the Development of Deaf Identity", Journal of Deaf Studies and Deaf Education, Volume 11, Nomor 4

Pawestri, Aprilina, (2017), "Hak Penyandang Disabilitas dalam Perspektif HAM Internasional dan HAM Nasional", Era Hukum - Jurnal Ilmiah Ilmu Hukum, Volume 2, Nomor 1, Juni 2017.

Putra, Ardylas Y, (2014), "Strategi BNN (Badan Narkotika Nasional) Kota Samarinda dalam Mensosialisasikan Bahaya Narkoba", Jurnal Ilmu Komunikasi, Volume 2, Nomor 2, 2014.

Sepdianus, Endang dan FX Sugiyanto, (2015), "Model Aktivitas Rekreatif Kompetitif untuk Meningkatkan Kesehatan Psikososial dan Memelihara Daya Ingat Lansia", Medikora, Volume 14, Nomor 2 
Sirbu, Anca, (2015), "The Significance of Language as a Tool of Communication", Scientific Bulletin Mircea cel Batran Naval Academy, Voume 18, Nomor 2

Siregar, Nina Siti Salmaniah, (2013), "Persepsi Orang Tua terhadap Penitngnya Pendidikan bagi Anak", Jurnal Ilmu Pemerintahan dan Sosial Politik, Volume 1, Nomor 1

Tarsidi, Didi, (2011), "Kendala Umum yang dihadapi Penyandang Disabilitas dalam Mengakses Layanan Publik", Jassi Anakku, Volume 10, Nomor 2

Utami, Ezza Oktavia, et al., (2018), "Aksesibilitas Penyandang Tunadaksa" Prosiding Penelitian dan Pengabdian kepada Masyarakat, Volume 5, Nomor 1, April 2018.

Widyonarso, Eko Setyo dan Yuliastuti, Nany, (2014), “Tingkat Aksesibilitas Fasilitas Sosial berdasarkan Konsep Unit Lingkungan di Perumnas Banyumanik Kota Semarang", Jurnal Ruang, Volume 2, Nomor 4

Badan Penelitian dan Pengembangan Kesehatan, (2013), Riset Kesehatan Dasar 2013, Hasil Penelitian, Kementerian Kesehatan Republik Indonesia, Jakarta.

Bharoto, Adhi Kusumo, (2017), dalam "Hak Penyandang Tuli Terabaikan", Kompas, 6 Maret 2017.

First Report of the Republic of Indonesia on the Implementation of the United Nations Convention on the Rights of Persons with Disabilities, 20 Desember 2016.

Laporan Bayangan Indonesia mengenai Implementasi Konvensi PBB Hak-Hak Penyandang Disabilitas, Maret 2017.

Lloyd, Karen, (2009), Policy on Early Intervention for Deaf and Hard of Hearing Children, Deaf Australia Inc, Australia.

Munro, Louise, (2010), The Development and Evaluation of a Culturally Affirmative Counseling Model for Deaf Clients in Australia, Desertasi, Faculty of Health Queensland University of Technology, Queensland.
Vaněk, Martin, (2009), Language Learning and Deafness, Desertasi, Faculty of Education Department of English Language and Literature Masarykova Univerzita, Brno, Ceko.

Meeras, Liis, (2010), Leisure and Recreation, University of Tartu, Parnu.

Palfreyman, Nick, (2015), "Budaya Tuli Indonesia dan Hak Bahasa", Coference Paper, Seminar Tahunan Linguistik, Universitas Pendidikan Indonesia, 4-5 Juni 2015.

Disability Unit, "Myths and Misconceptions about Deaf People", http://www.cput.ac.za/blogs/disability/disability -awareness/deaf-hearing-impairmentinfo/myths-and-misconceptions-about-deafpeoplel, diakses 24 September 2018.

DO-IT, "How are the Terms Deaf, Deafened, Hard of Hearing, and Hearing Impaired Typically Used?", https://www.washington.edu/doit/how-areterms-deaf-deafened-hard-hearing-andhearing-impaired-typically-used, diakses 9 Maret 2018.

Hidayat, Ali Akhmad Noor, "Penggunaan Bahasa Isyarat di Televisi akan Diwajibkan", https://bisnis.tempo.co/read/1035259/pengguna an-bahasa-isyarat-di-acara-televisi-akan-

diwajibkan/full\&view $=$ ok, diakses 10 Oktober 2018.

Iskandar, Adang, "Peduli Tuli", http://mediaindonesia.com/news/read/133795/p eduli-tuli/2017-11-26, diakses 9 Maret 2018.

Kementerian Kesehatan, "Rencana Strategis Kemenkes Tanggulangi Gangguan Pendengaran",

http://www.depkes.go.id/article/view/17030300 004/rencana-strategis-kemenkes-tanggulangigangguan-pendengaran.html, diakses 16 April 2018.

Kustiani, Rini, "Pusbisindo, Cara Unik Belajar Bahasa Isyarat", https://difabel.tempo.co/read/1109916/pusbisin do-cara-unik-belajar-bahasa-isyarat, diakses 9 Oktober 2018. 
DOI:

Queensland Health Multicultural Services, "How to Work with a Person who is Deaf or Hearing

Impaired",https://www.health.qld.gov.au/_dat alassets/pdf file/0024/157362/howtoworkwithd eaf.pdf, diakses 18 September 2018.

Rahmi, Ramadhany, "Gerkatin DIY Upayakan Aksesibilitas Layanan Publik untuk Tuli", https://www.solider.id/baca/4657-gerkatin-diyupayakan-aksesibilitas-layanan-publik-tuli, diakses pada 27 September 2018.
Tempo.co, "Sarana Pendidikan Inklusif Harus Diperluas", https://nasional.tempo.co/read/911696/saranapendidikan-inklusif-harus-

diperluas/full\&view $=$ ok, diakses 7 Oktober 2018.

United Nations, "Status of Treaties: Chapter IV Human Rights, Convention on the Rights of Persons with Disabilities", https://treaties.un.org/doc/Publication/MTDSG/ Volume\%20I/Chapter\%20IV/IV-15.en.pdf, diakses pada 27 September 2018. 